\title{
Anthocyanin-Rich Vegetables for Human Consumption-Focus on Potato, Sweetpotato and Tomato
}

\author{
Autar K. Mattoo ${ }^{1}$, Sangam L. Dwivedi ${ }^{2}$, Som Dutt ${ }^{3}$, Brajesh Singh ${ }^{3}$, Monika Garg ${ }^{4}$ and Rodomiro Ortiz ${ }^{5, * * 1}$ \\ 1 USDA-ARS, Sustainable Agricultural Systems Laboratory, Beltsville, MD 20705-2350, USA; \\ autar.mattoo@usda.gov \\ 2 Independent Researcher, Hyderabad 500016, India; sangam375@gmail.com \\ 3 Central Potato Research Institute, Shimla 171001, India; sd_bio@yahoo.com (S.D.); birju16@gmail.com (B.S.) \\ $4 \quad$ National Agri-Food Biotechnology Institute, Mohali 160071, India; monikagarg@nabi.res.in \\ 5 Department of Plant Breeding, Swedish University of Agricultural Sciences, Sundsvagen, 10 Box 190, \\ SE 23422 Lomma, Sweden \\ * Correspondence: rodomiro.ortiz@slu.se
}

Citation: Mattoo, A.K.; Dwivedi, S.L.; Dutt, S.; Singh, B.; Garg, M.; Ortiz, R. Anthocyanin-Rich Vegetables for Human Consumption-Focus on Potato, Sweetpotato and Tomato. Int. J. Mol. Sci. 2022, 23, 2634. https:// doi.org/10.3390/ijms23052634

Academic Editors: Salvador Rosello and Jaime Cebolla-Cornejo

Received: 23 January 2022

Accepted: 25 February 2022

Published: 27 February 2022

Publisher's Note: MDPI stays neutral with regard to jurisdictional claims in published maps and institutional affiliations.

Copyright: (C) 2022 by the authors. Licensee MDPI, Basel, Switzerland. This article is an open access article distributed under the terms and conditions of the Creative Commons Attribution (CC BY) license (https:// creativecommons.org/licenses/by/ $4.0 /)$.

\begin{abstract}
Malnutrition, unhealthy diets, and lifestyle changes have become major risk factors for noncommunicable diseases while adversely impacting economic growth and sustainable development. Anthocyanins, a group of flavonoids that are rich in fruits and vegetables, contribute positively to human health. This review focuses on genetic variation harnessed through crossbreeding and biotechnology-led approaches for developing anthocyanins-rich fruit and vegetable crops. Significant progress has been made in identifying genes involved in anthocyanin biosynthesis in various crops. Thus, the use of genetics has led to the development and release of anthocyanin-rich potato and sweet potato cultivars in Europe and the USA. The purple potato 'Kufri Neelkanth' has been released for cultivation in northern India. In Europe, the anthocyanin-rich tomato cultivar 'Sun Black' developed via the introgression of $A f t$ and atv genes has been released. The development of anthocyanin-rich food crops without any significant yield penalty has been due to the use of genetic engineering involving specific transcription factors or gene editing. Anthocyanin-rich food ingredients have the potential of being more nutritious than those devoid of anthocyanins. The inclusion of anthocyanins as a target characteristic in breeding programs can ensure the development of cultivars to meet the nutritional needs for human consumption in the developing world.
\end{abstract}

Keywords: biofortification; biosafety regulations; colored vegetables; flavonoids; gene editing; genetic tags; transgenes

\section{Introduction}

Anthocyanins (ACNs) and anthocyanidins are plant pigments, with flavylium (2-phenylch romenylium) ions being their basic core structure. ACNs are water-soluble, and present as a vacuolar pigment with a range of diverse colors (red, purple, black, or blue), while anthocyanidin is the sugar-free counterpart of anthocyanin. ACNs are the largest group of water-soluble pigments, located in the plant cell vacuoles. They are esterified with one or more acid groups, as acylated anthocyanins, and are characterized as acylated or nonacylated anthocyanins based on the presence or absence of the acyl group. Acylated anthocyanins constitute a variety of forms based on the number of acyl groups (mono-, di-, tri-, and tetraacylated anthocyanins). Differences in $\mathrm{pH}$, light, temperature, and structure influence the color and stability of ACNs. They appear red in acidic conditions but turn blue when the $\mathrm{pH}$ increases [1,2]. Acylated ACNs show higher stability and higher antioxidant activity than nonacylated types [3]. Fruits and vegetables (FV) contain both acylated and nonacylated ACN forms [2].

Fruits and vegetables with different colors provide a range of nutrients and bioactive compounds including phytochemicals, vitamins, minerals, and fibers [4]. ACNs have 
promising health-promoting groups of phytochemicals. Several reports involving doubleblind, randomized, and control trials have revealed dose-dependent effects of ACNs on chronic diseases, such as on glucose and lipid metabolism, weight management, plasma lipids and cholesterol efflux, or on platelet functions and cholesterol efflux in subjects with dyslipidemia [5-9]. Detecting either parent ACNs or their metabolites in tissue, as evidenced in mice kidney, liver, heart, and lung and pig brain tissues, could provide an evidentiary link between tissue ACNs and their associated health effects [10].

A two-prospective cohort and meta-analysis involving US men and women in 26 revealed nonlinear inverse associations of $\mathrm{FV}$ intake with total mortality and cause-specific mortality. Intake of $\approx 5$ servings per day of FV was associated with the lowest mortality, while intake above this level was not associated with additional risk reduction. Daily intake of 5 servings relative to the reference level ( 2 servings per day) was associated with hazard ratios $(95 \% \mathrm{CI})$ of $0.87(0.85-0.90)$ for total mortality, $0.88(0.83-0.94)$ for CVD mortality, 0.90 (0.86-0.95) for cancer mortality, and 0.65 (0.59-0.72) for respiratory disease mortality, with similar results (summary risk ratio of mortality for 5 servings per day was $=0.87$ with a $95 \% \mathrm{CI}$ in the $0.85-0.88 ; P_{\text {nonlinear }}<0.001$ ) based on dose-response metaanalysis that included 145,015 deaths accrued in 1,892,885 subjects. Thus, higher intakes of most subgroups of FV were associated with lower mortality [11].

Of late, several scientific articles, including original papers and reviews [12-18] have been published about the beneficial effects of anthocyanin on human health. There is thus an interest in such bioactive compounds, not only from a pharmaceutical standpoint but also from a nutraceutical perspective. Moreover, the use of biostimulants, mycorrhiza, and semi-natural compounds such as melatonin and phytomelatonin have been used to increase anthocyanin content in food crops, including FV [19-21].

In this review, we focus on the anthocyanins with specific reference to their useful variable germplasm, genetics, and molecular basis of inheritance. We also present data on functional and candidate genes as well as DNA markers associated with anthocyanins together with progress toward developing anthocyanins rich potato [Solanum tuberosum], sweet potato [Ipomoea batatas], and tomato [Solanum lycopersicum]) cultivars, which are the three most consumed vegetables, via crossbreeding and biotechnology.

\section{Natural Variation and Diversity in Gene Pools}

Germplasm is the main source for crop improvement programs because it represents a large pool of genetic diversity from which researchers can draw allelic variation for further use to develop, for instance, cultivars with significant nutritional and health benefits.

\subsection{High Throughput Assay}

Ultrasound-assisted extraction (UE) is an advanced green, fast, and ecological extraction technique to generate high-quality extracts from natural products with high precision (coefficient of variation less than 5\%) and reproducibility. The optimal extraction time determined for total phenols and total anthocyanins were 15- and 5-min, respectively. Temperature and percent methanol are the most influential variables. UE has been evaluated in determining total phenols and anthocyanins in berry crops, grape, and potato [22-25]. It is an ideal assay for quantifying total phenol and anthocyanin contents in plants. Interestingly, in sweet potato, the root-flesh color (red-purple, deep purple to white purplish) and their lightness values $\left(L^{*}\right)$ were negatively correlated $\left(R^{2}=0.65\right)$ with anthocyanin content [26]. Indirectly, this specified that deep-colored root-flesh contains more anthocyanins. Thus, intensity of color (more intense color, more anthocyanins) is a marker to identify high anthocyanins segregants in early generation breeding populations followed by wet chemistry tests on advanced breeding phenotypically uniform germplasm at later generations.

\subsection{Genotype $\times$ Environment Interactions (GEI)}

Differences in geographical locations due to variation in light intensity, photoperiod, temperature, soil fertility, stress levels, stage of tuber or storage root formation, and harvest 
all influence anthocyanin contents in potato and sweet potato. High temperature was found to decrease anthocyanin levels in purple-skinned and fleshed potato by $48 \%$ [27]. Thus, potatoes harvested in cooler climates produced 1.24 times more anthocyanins than those in warmer climates [28]. Potatoes grown under long days (14-15 h) and cooler temperatures accumulate about 2.5 times higher anthocyanin levels than those grown under short days (12-14 h) and higher temperatures [29]. Staggered harvest can affect anthocyanin content in potato due to variation in global solar irradiation $(\mathrm{r}<0.6252)$ [30]. Both growth environment (E) and genotype $(\mathrm{G})$ can cause significant $(p<0.01)$ differences in total anthocyanin content, with greater variation due to $G$ rather than $E$ in potato [31].

Overall, G, E, and GEI affect the content and composition of anthocyanins. Thus, multi-environment testing across diverse agro-ecologies has been recommended to identify stable and anthocyanin-rich germplasm for use in crop breeding as well as identifying sites more favorable to the production of anthocyanin-rich crops.

\subsection{Genetic Variation}

Fruits and vegetables in general contain higher amounts of anthocyanin compounds with more in fruits than in vegetables. The total anthocyanin content in FV may vary considerably among different plant genera, species and cultivars, and could be strongly influenced by light, temperature and agronomic factors. Phenol Explorer Online Database is a good source of information about anthocyanins in the plant kingdom. Euclidean distance-based cluster analysis

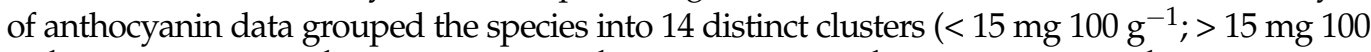

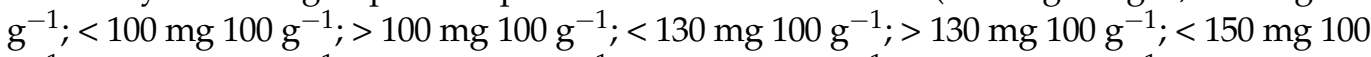

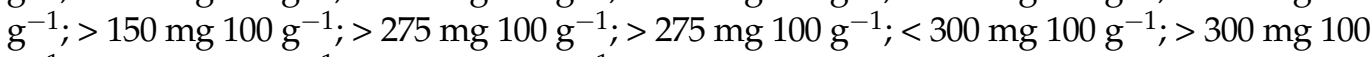

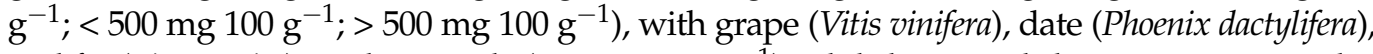

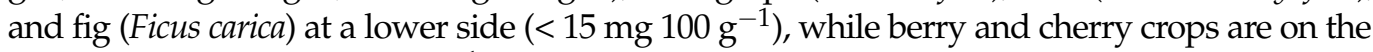
higher side (150-500 mg $100 \mathrm{~g}^{-1}$ ). Purple and red potatoes have anthocyanin levels of $\sim 15 \mathrm{mg}$

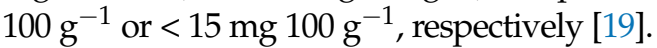

Differences in anthocyanin content that varied from 4-, 7-, 9-, and 95-fold in flesh and 9-fold in skin, were found among Andean potato germplasm [32-36]. Five anthocyanidins namely, delphinidin, cyanidin, petunidin, pelargonidin, and peonidin were quantified in tubers from 109 highly divergent diploid germplasm and found to differ in skin and flesh color, from yellow to purple, in the Colombian germplasm of Solanum tuberosum L. Group Phureja. Principal component analysis (PCA) clustered the accessions into six different groups with a majority of accessions in Group 1 represented by lowest concentrations of five anthocyanin compounds; group 2 had considerable variation in pelargonidin (17-38 mg 100 $\mathrm{g}^{-1}$ dry matter, DM); group 3 was represented by petunidin (19-76 $\left.\mathrm{mg} 100 \mathrm{~g}^{-1} \mathrm{DM}\right)$ and

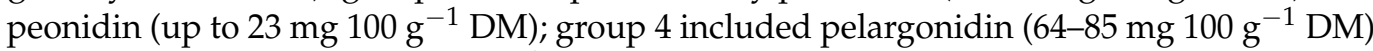
and petunidin (up to $28 \mathrm{mg} 100 \mathrm{~g}^{-1} \mathrm{DM}$ ); group 5 included accessions with highest content of pelargonidin (87-168 $\mathrm{mg} 100 \mathrm{~g}^{-1} \mathrm{DM}$ ) but had the lowest content of the remaining four anthocyanins; while group 6 represented accessions with lowest pelargonidin content but with higher concentrations of other four anthocyanins [37].

In the red- and purple-potato Korean cultivars and breeding clones, 26 anthocyanins were found, of which 24 were enriched in pelanin, peonanin, and petanin as principal anthocyanins while the red and purple potatoes grouped into distinct clusters [35]. Differences in anthocyanin patterns were also noted among native Andean potato germplasm. For example, red accessions contained predominantly pelargonidin derivatives, while the purple type had petunidin as a major anthocyanidin [32,33]. About 33\% (660 cultivated and 1960 wild accessions) of the 6100-potato germplasm housed in the genebank at The Leibniz Institute of Plant Genetics and Crop Plant Research (IPK; http:/ / glks.ipk-gatersleben.de/ home.php, accessed on 22 January 2022) are highly variable anthocyanin accessions in color patterns (partial to complete; peel and flesh containing the same color or colored peel and noncolored flesh; degree of pigmentation either spots, stripes, or rings). At five locations in the Czech Republic the total anthocyanins content included 16 red- and purplefleshed potatoes ranging from $0.7 \mathrm{mg} 100 \mathrm{~g}^{-1} \mathrm{FW}$ (cv. 'Blue Congo') to $74.3 \mathrm{mg} 100 \mathrm{~g}^{-1} \mathrm{FW}$ 
(cv. 'Blaue Ludiano'). 'Highland Burgundy Red' had a high proportion of pelargonidin (98.7\%), whereas 'British Columbia Blue' contained almost exclusively cyanidin. 'Violette' and 'Vitelotte' had a relatively high content of malvidin, while 'Shetland Black' had a higher content of peonidin (on average 36.7\%). Petunidin was found abundant in cultivars 'Valfi', 'Blue Congo', 'Salad Blue', 'Blaue St'. 'Galler', 'Blaue Hindel Bank', 'Blaue Ludiano', 'Blaue Schweden', 'Farbe Kartoffel' and 'Salad Red' [38]. Multi-fold differences in anthocyanins were reported among 26 potato cultivars differing in skin and flesh color that were evaluated for two seasons in New Zealand [39]. The total anthocyanin content in potato germplasm does not reach the level of anthocyanins reported in berry crops [19].

The structure and content of the secondary metabolites are likely to be affected by cooking because of high temperature $\left(\sim 100^{\circ} \mathrm{C}\right)$. However, cooking of pigmented potatoes still provided valuable levels of phenolic compounds and antioxidant activity independent of temperatures $[40,41]$.

CIP genebank include 16 purple-fleshed sweet potato (PFSP) accessions as sources of root anthocyanins (https: / / www.genesys-pgr.org/subsets/740f8b1e-8e3e-4773-a923-3 e84eda56932, accessed on 22 January 2022). Six-fold differences in anthocyanin contents among purple-fleshed sweet potato germplasm have been recorded [42].

In comparison to potato cultivars, tomato fruit is deficient in secondary metabolites such as flavonoids and anthocyanins [43], therefore its enrichment for these metabolites has been pursued through genetic engineering in recent years [44-48]. Nonetheless, wild tomatoes such as Solanum chilense, S. habrochaites, S. cheesmanii, and S. lycopersicoides, unlike the cultivated tomato, do produce anthocyanins in the sub-epidermal fruit tissue [49,50]. VIR Lycopersicon collection includes 7678 accessions of one cultivated and nine wild species [51]. A comparative assessment of 70 tomato accessions with different fruit colors unfolded substantial variation for biochemical composition, including anthocyanins. The anthocyanins in cultivated tomato with purple-red and yellow-purple fruits, respectively, ranged from 32.89 to 588.86 and 87.91 to $161.22 \mathrm{mg}^{-1} 100 \mathrm{~g}$, while in wild tomato fruits the anthocyanin levels varied from 84.31 to $152.71 \mathrm{mg}^{-1} 100 \mathrm{~g}$. Among cultivars, 'Ananas noire' and 'Indigo Clakamas Blue Berry' had exceptionally high anthocyanins: $430.30 \pm 98.35$ and $588.86 \pm$ $171.89 \mathrm{mg}^{-1} 100 \mathrm{~g}$, respectively. A dendrogram based on cluster analysis of biochemical parameters grouped the accessions into six clusters, where the first two clusters characterized accessions with high content of anthocyanins and chlorophylls and ascorbic acid in fruits [52]. A few VIR "Lycopersicon" accessions, unlike potato germplasm, had total anthocyanin in the range found for berry crops [19].

Genetic engineering involving specific transcription factors led to the enrichment of anthocyanins at concentrations that averaged $2.83 \pm 0.46 \mathrm{mg} \mathrm{g}^{-1}$ fresh weight [45]. Likewise, the cultivar 'Sun Black' (SB) developed by crossing an Anthocyanin fruit introgression line (Aft, LA1996) with atroviolaceum line (atv, LA0797) led to anthocyanin content similar to that found in anthocyanin-rich eggplant (Solanum melongena), red lettuce (Lactuca sativa), light-colored strawberry (Fragaria $\times$ ananassa), and cherry (Prunus cerasus) [48]. This research has demonstrated the power of genetic engineering as an important asset to develop anthocyanins-rich variants where crossbreeding programs are unable to deliver such a desired germplasm.

High anthocyanin content is associated with a bitter taste. However, the steamed tubers of two deep purple genotypes (MSU10010-43, 'Antin 3') and one white-purplish genotype (MSU1000115) showed differences in texture and taste [26]. Genotypic differences among purple-fleshed sweet potato genotypes were also reported for developing nutritious food products with respect to their physical properties (yield, lightness, hardness) and sensory attributes (color, aroma, texture, taste). For example, sweet potato genotypes with purple flesh in combination with yellow/orange or white color (MSU 06046-74, 'Antin $1^{\prime}$, MSU 06044-05) were suitable for making crispy chips followed by those with medium purple color ('Aya Murasaki', MIS 0612-73, MIS 0614-02, MIS 0601-22, MSU 06014-51). Conversely, sweet potato with deep purple color (MSU 06028-71, MSU 06046-48) was more 
suitable for noodles [42]. Such attributes may be exploited in breeding program to develop product-based sweet potatoes.

Genotypic differences in the accessibility and biotransformation of anthocyanins among cooked PFSPs were revealed via a dynamic in vitro human gastrointestinal (GI) model that stimulated gut digestive conditions, with accession-dependent variation in anthocyanin release and degradation [53]. These data suggested that intestinal and colonic microbial digestion of PFSP leads to an accession dependent pattern for anthocyanin accessibility and degradation. Moreover, clinical research plus in vitro and in vivo experiments demonstrated that anthocyanins have preventive and important positive effects on cardioprotection, neuroprotection, and antiobesity as also on antidiabetes and anticancer effects. This is likely due to the rapid absorption of ACNs such that they are seen in the bloodstream within a few minutes of consumption. It is hoped that more detailed research in the future may enable understanding the mechanisms involved whereby food components achieve such effects [54].

\subsection{Metabolite Diversity}

Secondary plant metabolites are essential for performing a variety of cellular functions essential for physiological processes including stress tolerance in plants and likely act as therapeutic agents for betterment of human health. These secondary metabolites are also a source of numerous medicinal compounds while their chemical structure diversity have made them also beneficial for treating serious diseases [55-57].

Metabolite profiling of selected 19 pigmented potato cultivars with different anthocyanin profiles in flesh (6 groups) and peel (18 groups) identified 21 anthocyanins including two new anthocyanins in potato (pelargonidin feruloyl-xylosyl-glucosyl-galactoside; cyanidin 3-p-coumaroylrutinoside-5-glucoside) [58]. Significant negative correlation between the main anthocyanins of red and blue potato cultivars was detected for some of the metabolites. This difference in anthocyanin profiles between red and blue potato cultivars possibly relates to regulation of the expression and activities of hydroxylases and methyltransferases rather than to differences for downstream glycosyl- and acyltransferases. Thus, such characterized cultivars represent a valuable genetic resource for the breeding and genetic research of potato anthocyanins [58].

Metabolite profiling of 27 sweet potato accessions including landraces and cultivars involving leaves and storage root tissues unraveled 130 metabolites (secondary metabolism including phenylpropanoids and carotenoids) [59] and lack of correlation between storage root phenotype and leaf metabolism. The accessions differing in root color (yellow, orange, purple) were also significantly different in primary metabolism [59]. Analysis of untargeted metabolomics of the purple-fleshed and one orange-fleshed sweet potato roots of three cultivars on average yielded $\sim 800 \mathrm{mg}$ anthocyanins $100 \mathrm{~g}^{-1}$ dry weight. It unfolded mostly acylated peonidin and cyanidin derivatives with $\sim 90 \%$ of the total anthocyanin signal, and over 350 flavonoid peaks with variable distribution [60]. Thus, metabolite profiling of germplasm provides an opportunity to identify differences in phenotypes/chemotypes and large structural diversity of anthocyanins and flavonoids in sweet potato.

An entire biosynthetic framework of polyphenol biosynthesis was unfolded via detailed annotation of metabolites and structural genes across S. lycopersicum and related species [61]. Identifying such large chemical diversity of polyphenolic compounds and their multiple physiological roles conferring beneficial traits is expected to accelerate omicsand metabolomics-assisted breeding to develop tailor-made tomato cultivars with specific flavonoids.

\section{Genetic and Molecular Basis of Variation}

\subsection{Anthocyanin Biosynthesis}

Anthocyanins constitute a ubiquitous part of flavonoids, a group of polyphenolic molecules in plants of which 600 are known [62]. They also protect plants against pathogens and radiation from UV $[63,64]$. Common anthocyanin derivatives include cyanidin, del- 
phinidin, malvidin, pelargonidin, peonidin, and petunidin [65]. Anthocyanins bring different and attractive colors to bear on their properties as well as their human health benefits [66,67]. Acetylation, glycosylation, and methylation of anthocyanidins is commonly found in plants and these processes are responsible for anthocyanin diversity [65]. Glycosylation of anthocyanins is catalyzed by glycosyltransferases and these forms are stable, located in vacuoles where they attract pollinators. Similarly, methylation of anthocyanins enables their stability and water solubility, in addition to their accumulation [68]. Non-methylated anthocyanidins, delphinidin, cyanidin, and pelargonidin glycosides contribute to $80 \%$ pigmented leaf, $69 \%$ fruit, and $50 \%$ flowers [69]. However, anthocyanidin modification is important for storage stability of pigmented anthocyanin [70,71] and takes place in the cytosol as soon as anthocyanindin is made [72,73].

Glycosylation at the anthocyanidin C-3 position of a hydroxyl group normally stabilizes anthocyanindins, increasing their hydrophilicity, and stabilizes their color linked to their glycosyl groups [71]. Glycosyltransferases catalyze 0 -glycosylation of anthocyanidin/anthocyanin recognizing UDP-sugar donors such as arabinose, galactose, glucuronic acid, glucose, xylose, and rhamnose.

Overexpression of anthocyanin acyltransferase(s) (AATs) has a great potential in enhancing the color stability of heterologous plants and result in color-modified flowers or plants [74]. DkMYB14 is a transcriptional activator/repressor that directly represses proanthocyanindin (PA) biosynthesis and promotes PA non-solubilization resulting in nonastringent persimmon [75]. On the other hand, MPK4 mediates MYB1 phosphorylation that results in induced anthocyanin accumulation [76]. It is also known that biosynthesis of anthocyanins is activated by a specific protein complex known as MBW (for MYB-bHLHWDR), which is highly conserved in most flowering plants [77]. In recent years, it has become evident that plants also harbor repressors of anthocyanin, for instance, proteins such as ITCP, HD-ZIP and NAC, which repress or destabilize MBW complex [78].

A huge number of phyto-flavonoids -which include polyphenols, phenolic acids and flavonoids-are now known. Anthocyanins are part of the largest group of plant phenols called flavonoids [43]. In the cultivated tomato fruit, flavonoids including anthocyanins are suboptimal or absent. Examples of the vegetative tissue of solanaceous plants enriched in anthocyanins include pepper [Capsicum annuum] (Figure 1A), eggplant (Figure 1B), tomato (Figure 1C), and potato tubers (Figure 1D,E) [79]. Biosynthesis of anthocyanin pathway is well characterized and conserved in plants $[66,80,81]$. This pathway initiates from 4-coumaroyl-CaO and malonyl COA catalyzed by the enzyme chalcone synthase (CHS) to synthesize naringenin chalcone which is then converted to naringenin by chalcone isomerase (CHI) (Figure 2a). Then, in a series of reactions, naringenin is converted to dihydrokaempferol, catalyzed by flavanonone $3^{\prime}$-hydroxylase (F3H). Flavonoid $3^{\prime}$-hydroxylase $\left(\mathrm{F}^{\prime} \mathrm{H}\right)$ thereafter hydroxylates dihydrokaempferol (DHK) into dihydroquercitin (DHQ) or to dihydro-myricetin (DHM) catalyzed by flavonoid $3^{\prime}, 5^{\prime}$-hydroxylase $3^{\prime} 5^{\prime} \mathrm{H}$. All three dihydroflavonols DHQ, DHM and DHQ are independently converted step wise to colorless leucoanthocyanidins by the enzyme dihydroflavonol 4-reductase (DFR). The next enzymatic reaction involves the enzyme anthocyanidin synthase (ANS), which converts all three leucoathocyanidins to colored anthocyanidins. Glucosides of peonidin, cyanidin, petunidin and malvinidin are shown in Figure 2b. Finally, the glycosyltransferases attach sugar molecules to the anthocyanidins. 

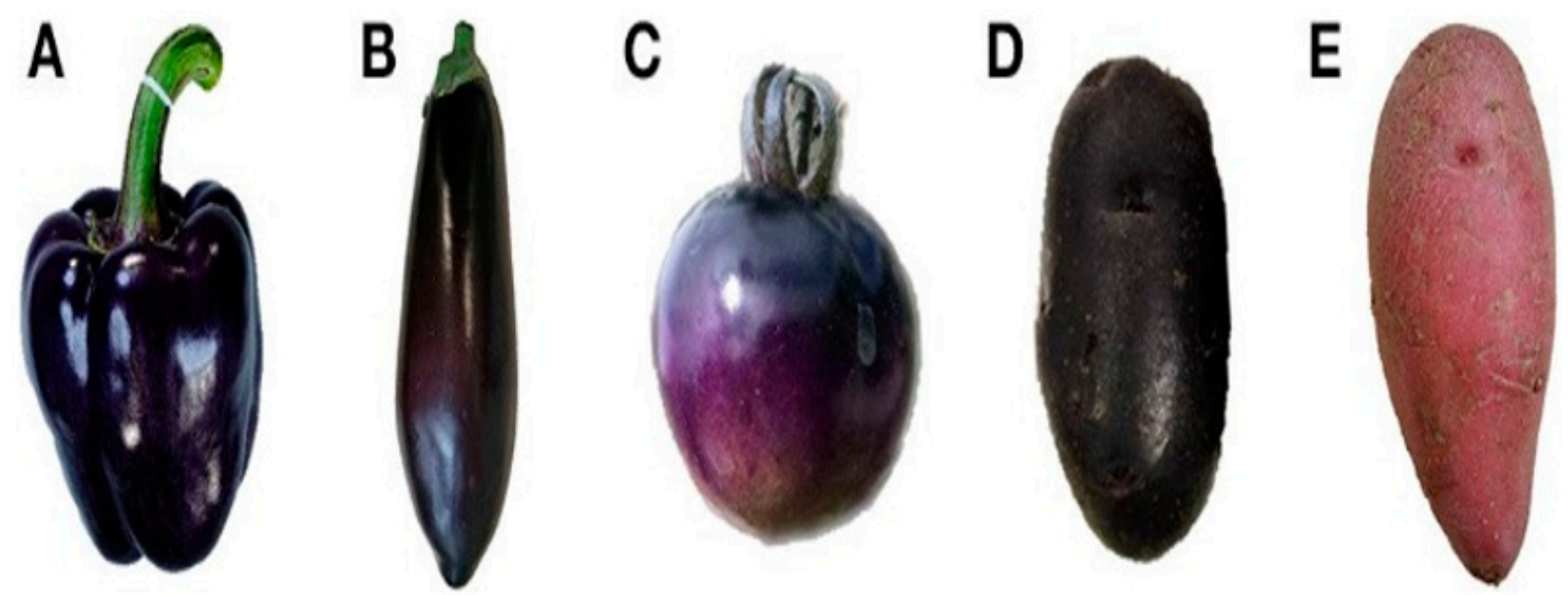

Figure 1. Solanaceous vegetables rich in anthocyanins: (A) purple pepper fruit, (B) purple eggplant fruit, (C) purple tomato fruit, (D) purple potato tuber, (E) red potato tuber. (After Liu et al. [66]; thanks to Frontiers in Chemistry).

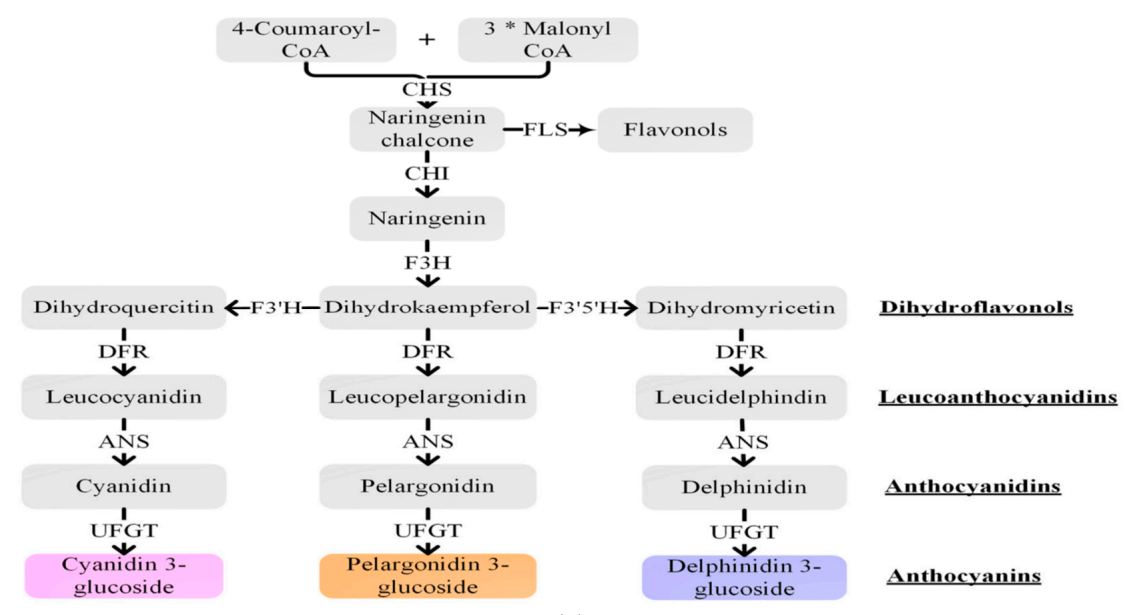

(a)

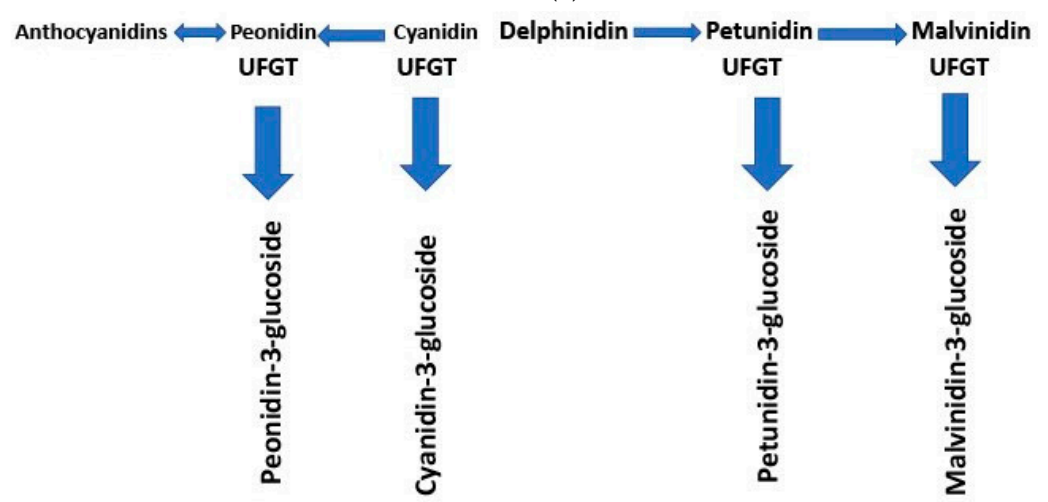

(b)

Figure 2. (a). Schematic representation of the anthocyanin biosynthetic pathway. CHS, chalcone synthase; $\mathrm{CHI}$, chalcone isomerase; $\mathrm{F} 3 \mathrm{H}$, flavanone 3-hydroxylase; F3' $\mathrm{H}$, flavonoid $3^{\prime}$-hydroxylase; $\mathrm{F}^{\prime} 5^{\prime} \mathrm{H}$, flavonoid 3',5'-hydroxylase; DFR, dihydroflavonol 4-reductase; ANS, anthocyanidin synthase; UFGT, flavonoid 3-O-glucosyltransferase; FLS, flavonol synthase. The "** means multiplication. After Liu et al. [66] (thanks to Frontiers in Chemistry). (b). Glucosides of other anthocyanidins. Shown are peonidin made from cyanidin while delphinidin is converted to petunidin, which in turn is converted to malvinidin (thanks to Dr. Tahira Fatima for help with this figure. See above text for details). 


\subsection{Functionally Characterized Genes Associated with Anthocyanins}

Understanding the genetic and molecular basis and identification of genetic tags with trait expression offers great promise to enhance crop breeding efficiency. These genetic tags are defined as strings of DNA that can be used to identify novel allelic variation associated with agriculturally beneficial traits. A candidate gene is a gene identified by its position in a chromosome that relates to trait expression. Such candidates need to be, however, functionally validated prior to being deployed in crop breeding. Here, we focus on functionally characterized genes and recently discovered "candidate" genes associated with anthocyanins.

Genome-wide association analysis involving single nucleotide polymorphisms (SNPs) and diploid potato germplasm of Solanum tuberosum L. Group Phureja from Colombia unraveled seven quantitative trait loci (QTL) associated with variation in anthocyanin content. QTL on chromosomes 1 and 10 were found to be the most stable. Three of the seven QTL were similar to previously reported genes involved in the regulation of anthocyanins in potato tubers [37]. In a diverse collection of native landraces of diploid potatoes, phenylalanine-ammonia lyase $(P A L)$ gene was contained in the region on chromosome 10, which also harbors other significant SNPs as well as multiple anthocyanin homologs, and is associated with five anthocyanin compounds. PAL being pleiotropic is an excellent target for breeding programs as it repeatedly produces significant differences in anthocyanins by recurrent selection. The short distance between PAL and multiple MYB transcription factors (TFs) linked with anthocyanin accumulation in potato demonstrated that loci identified in QTL mapping may harbor multiple causal genes. Most potatoes with high anthocyanin content share the same genotype at this cluster, which suggests presence of recurrent selection on the same alleles. Thus, this region has high diversity, consistent with balancing artificial selection to breed potatoes with diverse colors [82].

StAN1 (ANTHOCYANIN1), located on chromosome 10, is a major regulatory gene that controls anthocyanin biosynthesis in potato tubers. The currently available diagnostic markers for identifying functional StAN1 alleles (StAN1777, StAN1816) are not efficient to predict potato pigmentation patterns. Thus, there is a need for developing additional diagnostic markers for anthocyanin synthesis that can be used efficiently in potato breeding [83]. This lack of anthocyanins in some potato genotypes may be due to mutation of a structural gene as was evidenced in the case of $S t F 3^{\prime} 5^{\prime}$, which partially disrupts anthocyanin synthesis that does not affect red but only blue and purple pigmentation. Thus, it is an attractive target for marker-aided identification of potatoes with purple or red flesh tubers [84].

In sweet potato, 22 of the 156 MYB-like genes were highly positively or negatively correlated with the anthocyanin content in leaves or storage roots. IbMYB1 is one of the major anthocyanin biosynthesis regulatory genes. IbMYB1 constitutes three members, $I b M Y B 1-1, I b M Y B 1-2 a$, and IbMYB1-2b, of which, the latter two are not necessary for anthocyanins accumulation in cultivated species that have purple shoots or purplish rings or spots of flesh. The persistent and vigorous expression of IbMYB1 is essential to maintain the purple color of leaves and storage roots. It is an early response gene of anthocyanin biosynthesis. IbMYB2s, the highest similarity genes of $I b M Y B 1$, are not the members of $I b M Y B 1$, thereby suggesting there may be more members of IbMYB1 involved in the regulation of anthocyanin biosynthesis [85]. A genome wide association study (GWAS)eQTL analysis revealed IbMYB1-2 as a master regulator and a major gene responsible for the activation of anthocyanin biosynthesis in the storage roots of sweet potato [86].

A novel complex of TFs (namely, IbEFR71-IbMYB340-IbbHLH2), coregulate anthocyanin biosynthesis by binding to the IbANS1 promoter in purple-fleshed sweet potato evidenced by higher expression levels of IbERF71, IbMYB340 and IbbHLH2 in purplefleshed sweet potatoes. The expression levels were positively correlated with anthocyanin contents. Co-transformation of IbMYB340-IbbHLH2 resulted in anthocyanin accumulation in tobacco leaves and strawberry receptacles, while the addition of IbERF71 significantly intensified the color. TFs together significantly increased the expression levels of FvANS and FvGST, which are involved in anthocyanin biosynthesis and transport in strawberry, 
respectively. Thus, work with this crop unfolded a new regulatory network of anthocyanin biosynthesis in purple-fleshed sweet potatoes [87].

Arabidopsis seedlings overexpressing IbWD40 accumulate anthocyanins [88]. Expression of $I b W D 40$ plays a role in the regulation of anthocyanin biosynthesis in purple sweet potato. Comparative analysis of transcriptome between anthocyanin-containing and anthocyanin-free sweet potato lines unfolded 2329 unigenes that were differentially expressed, of which 1235 were up-regulated and 1094 were down-regulated. The up-regulated unigenes were enriched in the flavonoid and phenylpropanoid biosynthesis pathways, while the down-regulated unigenes were enriched in plant hormone GA signal transduction pathway. The gene co-expression network analysis of differentially expressed unigenes showed that anthocyanin biosynthesis genes were co-expressed with the transcripts related to MYB, bHLH and WRKY TFs [89].

Solanum chilense Anthocyanin fruit (AftAft/-) and atroviolacea (atvatv) loci contribute to increased anthocyanin accumulation in fruits of cultivated tomato [90-92]. The CRISPR/Cas9mediated Slan 2 mutants had fruit color and anthocyanin content similar to the wild type (WT) cv. 'Indigo Rose'. However, in the SlAN2 mutant, the anthocyanin content and relative expression levels of anthocyanin-related genes were significantly lower in vegetative tissues relative to WT [93]. Another putative candidate gene Slan2-like in the Aft locus fine mapped to an approximately 145-kb interval on chromosome 10. The CRISPR/Cas9mediated Slan2-like mutants in comparison to WT showed much lower anthocyanins due to the downregulation of multiple anthocyanin genes. This suggests that Slan2-like may be a good candidate gene to enhance the anthocyanin content in tomato [94]. Alternative splicing is "a process that allows the generation of different forms of mature mRNA from the primary gene transcript" [95]. A study on comparative functional analysis of R2R3 MYB transcription factors in wild-type and Aft plants demonstrated significant differences both in the expression level and protein functionality of Slan2like. Splicing mutations resulted in a complete loss of function of the WT protein, thereby indicating its key role in the anthocyanin pigmentation in tomato fruit [96]. The photomorphogenesis-related TF SIBBX20 regulates anthocyanin accumulation in tomato [97]. SIBBX20 promotes anthocyanin biosynthesis by binding the promoter of the anthocyanin biosynthesis gene SIDFR. SIBBX20 interacts with COP9 signalosome subunit SICSN5-2. Silencing of SICSN52 led to anthocyanin hyperaccumulation in transgenic tomato calli and shoots, while SICSN5-2 overexpression decreased anthocyanin accumulation, thereby suggesting that SIBBX20-SICSN5 modulation may represent a novel regulatory pathway in light-induced anthocyanin biosynthesis in tomato [98].

Significant progress has been made in identifying genes associated with anthocyanin biosynthesis in food crops, some of which have been functionally characterized (Table 1). However, a focused approach is needed to functionally characterize other "candidate" genes to ascertain their involvement in anthocyanin biosynthesis and to develop genetic tags for use as aids in crossbreeding.

Table 1. Candidate or functionally characterized genes regulating anthocyanin biosynthesis in potato, sweet potato, and tomato.

\begin{tabular}{|c|c|c|}
\hline Gene & Description & Reference \\
\hline \multicolumn{3}{|c|}{ Potato } \\
\hline$P A L$ & $\begin{array}{c}\text { PAL, being in close proximity of multiple MYB TFs on chromosome 10, linked with } \\
\text { anthocyanin accumulation; it being pleiotropic an excellent target for enhancing } \\
\text { anthocyanin content by recurrent selection }\end{array}$ & [82] \\
\hline$S t F 3^{\prime} 5^{\prime}$ & $\begin{array}{c}\text { Partially disrupt anthocyanin synthesis affecting blue and purple but not red } \\
\text { pigmentation; attractive target for marker-aided identification of potatoes with } \\
\text { purple or red flesh color tubers }\end{array}$ & [84] \\
\hline \multicolumn{3}{|c|}{ Sweet Potato } \\
\hline$I b M Y B 1$ & A major anthocyanin biosynthesis regulatory gene & [85] \\
\hline
\end{tabular}


Table 1. Cont.

\begin{tabular}{|c|c|c|}
\hline Gene & Description & Reference \\
\hline \multicolumn{3}{|c|}{ Potato } \\
\hline & IbERF71-IbMYB340-IbbHLH2, a novel TF complex, coregulate anthocyanin & \\
\hline $\operatorname{IbANS1}$ & $\begin{array}{l}\text { biosynthesis by binding to the IbANS1 promoter in purple-fleshed sweet potatoes } \\
\text { than other color cultivars; expression levels positively correlated with anthocyanin }\end{array}$ & {$[87]$} \\
\hline & contents & \\
\hline & IbMYB1 expressed in purple-fleshed cultivars but not in other with orange-, & \\
\hline$I b M Y B 1, I b W D 40$ & $\begin{array}{l}\text { yellow-, or white-fleshed color; } I b W D 40 \text { expression limited to one anthocyanin rich } \\
\text { cultivar; Arabidopsis seedling overexpressing } I b W D 40 \text { accumulated anthocyanins, } \\
\text { indicating that it regulates anthocyanin biosynthesis in purple sweet potato }\end{array}$ & {$[88]$} \\
\hline \multicolumn{3}{|c|}{ Tomato } \\
\hline SIDFR & $\begin{array}{l}\text { SIBBX20 promotes anthocyanin biosynthesis by binding the promoter of the } \\
\text { anthocyanin biosynthesis gene SIDFR }\end{array}$ & {$[98]$} \\
\hline Slan2 & Slan 2 mutants regulate anthocyanins in Aft locus & [93] \\
\hline Slan2-like & Slan2-like mutants downregulate anthocyanins in Aft locus & [94] \\
\hline
\end{tabular}

\section{Biofortification to Redesign Next-Generation Anthocyanins Rich Vegetable Crops}

Biofortification refers to the development of nutrient- or phytochemical-dense crops using crossbreeding or genetic engineering. It is a sustainable and cost-effective strategy to address all forms of malnutrition, particularly in the developing world. Crop biofortification has been successful in developing and releasing micronutrients (Fe and $\mathrm{Zn}$ ) or provitamin A dense grain and root (orange-fleshed sweet potato, OFSP) crops across continents $[99,100]$. Micronutrient deficiency is widespread in the Africa, Asia, and Latin America, and regular consumption of biofortified crops has been shown to increase micronutrient intakes and thus help meet the sustainable development goals [101]. Integrating high seed nutrients $(\mathrm{Fe}, \mathrm{Zn})$ density with greater pro vitamin $\mathrm{A}$ and flavonoids (anthocyanin) as strategy in breeding program may provide lasting solution to overcome all forms of malnutrition in developing economies.

\subsection{Crossbreeding and Genomic-Assisted Breeding}

A few anthocyanin-rich potato and sweet potato cultivars have been released for cultivation in India. A new specialty table potato cultivar named 'Kufri Neelkanth' ensued from crossbreeding (https:/ /icar.org.in/content/kufri-neelkanth-new-antioxidant-rich-potatovariety-developed-icar-central-potato-research, accessed on 22 January 2022). The average tuber yield of 'Kufri Neelkanth' ranges from 35 to $38 \mathrm{t} \mathrm{ha}^{-1}$, which is much higher than the Indian national average of $23 \mathrm{tha}^{-1}$. It is speculated that once this cultivar is commercially grown, it would be a boon to farmers in the northern Indian plains, in particular Punjab where 2.7 million $t$ of annual potato production is known and 60 to $70 \%$ of seed potato is distributed to domestic markets https:/ / www.potatopro.com/news/2019/newly-bredindian-potato-variety-said-be-rich-antioxidants-ready-commercial-production, accessed on 22 January 2022).The sweet potato 'Bhu Krishna' has been bred in India [102] while sweet potato cultivar 'P 4', potato cultivars 'AmaRosa', 'Purple Pelisse', and 'Terra Rossa' have been bred in the USA [103-106]. The colored potato cultivars are widely cultivated in Europe, South America, North America, and to a lesser extent in Asia [14,75]. Anthocyaninrich (0.04 to $0.12 \mathrm{mg} \mathrm{g}^{-1}$ fresh tuber weight) advanced CIP potato clones, including CIP302281.25, CIP302302.34, CIP302299.16, CIP302288.35, CIP302281.39, CIP302298.44, CIP302298.16, CIP302304.27, and CIP302306.33, are being globally utilized in potato breeding for developing locally-adapted anthocyanin-rich cultivars (https:/ / research.cip.cgiar. org / cipcatlg_ac / breeders.php?language=1\&name=English, accessed on 22 January 2022).

Genetic engineering has become an ideal tool to develop anthocyanin-rich tomatoes $[48,96]$. Some wild tomato species, such as $S$. chilense and S. cheesmaniae, biosynthesize anthocyanins in the fruit sub-epidermal tissue, and some alleles from those genotypes have been introgressed into a newly developed purple tomato line named 'Sun Black' 
(SB). This tomato cultivar has a deep purple skin color due to higher anthocyanins in the peel, and a normal red-colored pulp and taste similar to traditional tomato has been released in Italy utilizing a crossbreeding approach [107]. Notably, a blue-colored tomato with high anthocyanin levels had been released earlier in the USA [108]. A breeding line with purple fruit color was bred by involving in its development 'OSU blue' (blue fruit) and 'Purple mini' (brown fruit). In this line, both the early and late biosynthesis genes (except Sl5GT) related to anthocyanin biosynthesis are upregulated in the peels of purple tomato fruits. The expression of regulatory genes SIANT1 and SIAN1 dramatically increased in the peels of purple tomato fruits, thereby suggesting that both genes control anthocyanin biosynthesis in the peels of purple-fruited tomatoes via the up-regulation of structural genes in the anthocyanin pathway. It is therefore an important genetic resource for use in potato breeding [109].

An introgression line carrying anthocyanin biosynthesis regulatory genes (Aft, atv, hp2) in the genetic background of red-fruited tomato showed enhanced accumulation of anthocyanins and bioactive compounds and distinct changes in volatile compounds [110]. Stacking of lycopene $(d g)$ and anthocyanin $(A f t)$ synthesizing genes led to selection of a purplefruited tomato (AftAftdgdg) with exceptionally high levels of lycopene $\left(\sim 6 \mathrm{mg} 100 \mathrm{~g}^{-1}\right.$ fresh weight, FW), anthocyanin ( 21 mg 100g $\left.{ }^{-1} \mathrm{FW}\right)$, and ascorbic acid ( 31 $\left.\mathrm{mg}^{-1} \mathrm{FW}\right)$ [111]. Interestingly, a red-fruited tomato line was converted into a purple-fruited commercial cherry line LAM374 stacking Aft, atv, and $h p 2$ alleles [112].

Significant progress has been made in developing anthocyanins-rich potato, sweet potato, and tomato cultivars, advanced breeding lines, and genetic stocks (Table 2). Combining high anthocyanins into improved genetic backgrounds is a significant breeding challenge [113]. A more directed effort is needed to recycle the currently available anthocyaninsrich gene pools in crop breeding to increase yield ceilings, especially among anthocyaninrich grain crops. However, phenolic compounds including high levels of anthocyanin can diminish iron absorption from anthocyanin rich vegetables [114].

Table 2. List of anthocyanins-rich potato, sweet potato and tomato cultivars/advanced breeding lines and genetic stocks developed through crossbreeding and selection.

\begin{tabular}{|c|c|c|}
\hline Cultivar & Characteristics & Reference \\
\hline \multicolumn{3}{|c|}{ Potato } \\
\hline 'Kufri Neelkanth' & $\begin{array}{l}\text { Adapted for cultivation in northern Indian plains; much higher yield } \\
\text { (35 to } 38 \mathrm{t} \mathrm{ha}^{-1} \text { ) compared to national average of } 23 \mathrm{t} \mathrm{ha}^{-1} \\
\text { anthocyanin }>100 \mu \mathrm{g} 100 \mathrm{~g}^{-1} \text { fresh weight (FW) [115] }\end{array}$ & $\begin{array}{c}\text { https: } \\
\text { //icar.org.in/content/ } \\
\text { kufri-neelkanth-new- } \\
\text { antioxidant-rich-potato- } \\
\text { variety-developed-icar- } \\
\text { central-potato-research, } \\
\text { accessed on 22 February } \\
2022\end{array}$ \\
\hline $\begin{array}{l}\text { 'Puma Makin', 'Leona', } \\
\text { 'Yawar Manto', 'Añil', } \\
\text { 'Sangre de Toro', } \\
\text { 'Qequrani' }\end{array}$ & $\begin{array}{l}\text { Native pigmented (red and purple) cultivars grown in Huancavelica } \\
\text { region of Peru; Anthocyanin: 'Puma Makin', } 74.3 \mathrm{mg} \mathrm{kg}^{-1} \text { skin dry } \\
\text { weight, SDW; Leona, } 6.32 \mathrm{mg} \mathrm{kg}{ }^{-1} \text { flesh dry weight, FDW and } \\
166.65 \mathrm{mg} \mathrm{kg}^{-1} \mathrm{SDW} \text {; 'Yawar Manto', } 602.9 \mathrm{mg} \mathrm{kg}{ }^{-1} \mathrm{FDW} \text { and } \\
709.4 \mathrm{mg} \mathrm{kg}^{-1} \mathrm{SDW} \text {;'Añi', } 104 \mathrm{mg} \mathrm{kg}^{-1} \mathrm{FDW} \text { and } 273.9 \mathrm{mg} \mathrm{kg}^{-1} \\
\text { SDW; 'Sangre de Toro', } 27.5 \mathrm{mg} \mathrm{kg}^{-1} \mathrm{FDW} \text { and } 124.2 \mathrm{mg} \mathrm{kg}^{-1} \mathrm{SDW} \text {; } \\
\text { 'Qequrani', } 10.2 \mathrm{mg} \mathrm{kg}^{-1} \mathrm{FDW}\end{array}$ & {$[32]$} \\
\hline $\begin{array}{c}\text { 'AmaRosa', 'Purple } \\
\text { Pelisse', and 'Terra Rossa' }\end{array}$ & $\begin{array}{l}\text { Released for cultivation in USA ('AmaRosa': Total anthocyanin content } \\
\text { (TAC) } 18.2 \mathrm{mg} \text { compared to } 13.8 \mathrm{mg} 100 \mathrm{~g} \text { FW in control 'All Blue'; } \\
\text { 'Purple Pelisse': TAC } 34.2 \mathrm{mg} \text { compared to } 12.6 \mathrm{mg} 100 \mathrm{~g} \text { FW in control } \\
\text { 'All Blue') }\end{array}$ & [104-106] \\
\hline 'Hongyoung', 'Jayoung' & $\begin{array}{l}\text { Released for cultivation in South Korea ('Hongyoung': TAC } 31.8 \mathrm{mg} \\
100 \mathrm{~g} \mathrm{FW}, 3.6 \text { times higher than control Jasim) }\end{array}$ & {$[116,117]$} \\
\hline
\end{tabular}


Table 2. Cont.

\begin{tabular}{|c|c|c|}
\hline Cultivar & Characteristics & Reference \\
\hline \multicolumn{3}{|c|}{ Potato } \\
\hline $\begin{array}{l}\text { 'Hermanns Blaue', } \\
\text { 'Vitelotte', 'Shetland Black', } \\
\text { 'Valfi' }\end{array}$ & European blue-fleshed potato cultivars & [118] \\
\hline \multicolumn{3}{|c|}{ Sweet Potato } \\
\hline $\begin{array}{c}\text { 'Antin 1', 'Antin 2', 'Antin } \\
3^{\prime}\end{array}$ & Released in Indonesia (TAC 8.4, 130.2, and $150.7 \mathrm{mg} 100 \mathrm{~g}^{-1} \mathrm{FW}$ ) & {$[26]$} \\
\hline 'Bhu Krishna' & Released in India (TAC $90.0 \mathrm{mg} 100 \mathrm{~g}$ compared to nil in control) & [102] \\
\hline $\mathrm{P} 4$ & Released in USA (TAC up to $14 \mathrm{mg}$ g DW) & [103] \\
\hline $\begin{array}{l}\text { 'Borami', 'Mokpo 62'; } \\
\text { 'Shinzami', 'Zami' }\end{array}$ & Released in South Korea & {$[119]$} \\
\hline $\begin{array}{l}\text { 'Yamagawamurasaki', } \\
\text { 'Ayamurasaki', 'Chiran }\end{array}$ & & \\
\hline $\begin{array}{l}\text { Murasaki', 'Tanegashima } \\
\text { Murasaki', 'Naka } \\
\text { Murasaki', 'Purple Sweet' }\end{array}$ & Released for cultivation in Japan & [120] \\
\hline \multicolumn{3}{|c|}{$\begin{array}{c}\text { Tomato } \\
\text { Fnhanced accumulation of anthocvanins and hioactive comnounds }\end{array}$} \\
\hline Near isogenic line (NIL) & $\begin{array}{l}\text { Enhanced accumulation of anthocyanins and bioactive compounds } \\
\text { with distinct changes in volatile compounds in NIL carrying Aft, atv, } \\
\text { and } h p 2 \text { in the genetic background of red-fruited tomato }\end{array}$ & [110] \\
\hline Breeding line & $\begin{array}{l}\text { A purple-fruited line derived from a cross between 'OSU blue' (blue } \\
\text { fruit) and 'Purple mini' (brown fruit) }\end{array}$ & [109] \\
\hline 'Sun Black' & $\begin{array}{l}\text { Deep purple skin but with a normal red color pulp and taste similar to } \\
\text { traditional tomato released in Europe; TAC 7.1 mg } 100 \mathrm{~g} \mathrm{FW,} \\
\text { comparable to eggplant or red cherry [48] }\end{array}$ & [107] \\
\hline 'Indigo Rose' & $\begin{array}{c}\text { A blue colored tomato released for cultivation in USA (TAC up to } \\
10 \mathrm{mg} 100 \mathrm{~g} \mathrm{~g}^{-1} \mathrm{FW} \text { on a whole fruit basis, normal tomato fruits devoid } \\
\text { of anthocyanin) }\end{array}$ & [108] \\
\hline
\end{tabular}

\subsection{Transgenes and CRISPR/Cas9 Systems to Enrich Anthocyanins}

Genetic engineering of anthocyanin biosynthesis pathway in staple crops can provide health promoting food in abundance to minimize the risk of NCDs in humans. As stated above, anthocyanin biosynthesis pathway is complex and regulated by complex genetic network that involves both structural and regulatory genes. However, success has already been achieved in enhancing anthocyanin levels in potato, sweet potato and tomato with little or no adverse impact on plant growth and development. Anthocyanin biosynthesis regulation is fairly conserved among plants; however, different isoforms of anthocyanin-related genes between cultivars results in tissue-specific accumulations of purple pigments. The key targets identified for developing the anthocyanin-rich cultivars through genomic-assisted breeding approaches include MYB-bHLH-WD40 TFs [121-123]. Leaf Color (Lc) TF gene enabled sweet potato transformation increasing both content (1.5-1.9 times compared to the respective WT) and composition (17 anthocyanins in WT and 19 in transgenic lines), while some individual anthocyanins increased by 4.5 times and others decreased by $\sim 2$ times [124].

Transgenic tomato plants modified using Delila and Rosea1 genes from snapdragon (Antirrhinum majus) were enriched with a 70 to 100 -fold increase in anthocyanin content in purple fruit [47]. These transgenic plants had no negative effects on other quality attributes such as total carotenoids, including lycopene levels. Similarly, Delila and Rosea1 genes from transgenic tomato cultivar 'Micro-Tom' were transferred to tomato cultivar 'Moneymaker' by crossbreeding which resulted in the enhancement of fruit anthocyanin by $131 \%\left(3 \mathrm{~g} \mathrm{~kg}^{-1}\right.$ dry matter) [125]. In addition to these studies, when the SlMYB75 gene was overexpressed in tomato fruit, multiple quality traits were improved, e.g., anthocyanin content reached $1.86 \mathrm{mg} \mathrm{g}^{-1}$ fresh weight and total phenolics, flavonoids and soluble solids relative to WT increased by 2.6-, 4-, and 1.2-fold, respectively [126]. Also, the aroma volatiles (aldehyde, phenylpropanoid-derived and terpene volatiles) significantly increased in the transgenic 
tomato fruit as compared to WT. The transcript profiling of these transgenic tomatoes revealed that the genes involved in ethylene signaling, phenylpropanoid and isoprenoid pathways were upregulated, thus suggesting that SIMYB75 is a key regulator of fruit quality attributes [126].

\subsection{Biosafety Regulation and Acceptability of Genetically Modified Anthocyanin-Rich Vegetables}

The transgenic "anti-cancer" purple tomato-expressing two snap dragon genes with increased anthocyanin content-captured the attention of potential end-users due to its proposed human health benefit $[45,47]$. Some grocery shops are reluctant to sell the transgenic anthocyanin-rich tomatoes because they think consumers may reject such produce, and their imagined concern about the safety of transgenic-derived food [127,128]. Biosafety assessment, however, indicated that carotenoid levels did not change in the anthocyanin-rich lines, thus indicating the stability of the transgene [33]. It is now considered by the US Food and Drug Administration (FDA) that plant-edited produce can be cultivated and sold with no regulation.

\section{Concluding Remarks}

Secondary metabolism in plants is a source of several potential bioactive compounds some of which have been linked to human health. Anthocyanins belong to a major group of polyphenolic molecules called flavonoids. The biosynthetic pathway(s) leading to synthesis of these bioactive compounds is (are) regulated by a complex of structural and regulatory genes as well as environmental cues. Hence, anthocyanin biofortification will require new knowledge and advancements in gene stacking through crossbreeding programs and metabolic engineering to ensure rich germplasm for nutrition needs of growing human population particularly in the developing world. Such advancements may also ensure that commodities deficient in anthocyanins, such as a commonly bred tomato, can generate a good dose of nutritional molecules. Notably, genetic engineering technology successfully led to the enhancement of the phytonutrient content of the anti-cancer carotenoid lycopene (by 200-300\%), juice quality, and vine life of tomato fruit [44]. Moreover, as discussed above, engineering of transcription factors and gene editing technology were successfully applied in developing anthocyanin-rich food crops without any significant yield penalty. Biofortification (of both micronutrients and phytochemicals) utilizing metabolic engineering can potentially eradicate malnutrition and thereby enhance global human health [129]. An approach to eating a balanced diet, saving land area, and reducing greenhouse gas emissions would require more production and consumption of fruits and vegetables and diets high in desirable proteins [130]. Public policy targeting the constraints to produce and consumption of fruits and vegetables is needed. A portfolio of interventions and investments that focus on fruit and vegetable production, technologies and practices to reduce waste without increasing consumer cost, and educating the public in large on healthy and tested diets [131].

Author Contributions: Conceptualization, S.L.D., R.O. and A.K.M.; investigation, S.L.D., R.O. and A.K.M.; writing — original draft preparation, S.L.D., S.D., B.S., M.G., R.O. and A.K.M.; writing-review and editing, S.L.D., R.O. and A.K.M.; project administration, R.O. All authors have read and agreed to the published version of the manuscript.

Funding: This review received no external funding.

Institutional Review Board Statement: Not applicable.

Informed Consent Statement: Not applicable.

Data Availability Statement: Not applicable.

Acknowledgments: Sangam L. Dwivedi thanks Ramesh Kotana, Senior Manager, Indian School of Business (ISB), Hyderabad, India for arranging reprints on anthocyanins as valuable literature resources that helped him draft his part of contribution to this manuscript. Rodomiro Ortiz acknowledges the grant funding through the PlantePigment and Annatto projects led by Chr.HansenA/S through the projects from Green Development and Demonstration Program (GUDP, Denmark) and 
Innovationsfonden (Denmark), respectively. Autar K. Mattoo thanks the support of the United States Department of Agriculture, Agricultural Research Service, Sustainable Agricultural Systems Laboratory, Beltsville, MD 20705-2350, USA, as well as to Frontiers in Chemistry for Figures 1 and 2 presented in the text. Monika Garg acknowledges the funding support of the Department of Biotechnology, New Delhi, India.

Conflicts of Interest: The authors declare no conflict of interest.

\section{References}

1. Khoo, H.E.; Azlan, A.; Tang, S.T.; Lim, S.M. Anthocyanidins and Anthocyanins: Colored Pigments as Food, Pharmaceutical Ingredients, and the Potential Health Benefits. Food Nutr. Res. 2017, 61, 1361779. [CrossRef] [PubMed]

2. Gamage, G.C.V.; Lim, Y.Y.; Choo, W.S. Sources and Relative Stabilities of Acylated and Nonacylated Anthocyanins in Beverage Systems. J. Food Sci. Technol. 2021, 59, 831-845. [CrossRef]

3. Hu, N.; Zheng, J.; Li, W.; Suo, Y. Isolation, Stability, and Antioxidant Activity of Anthocyanins from Lycium ruthenicum Murray and Nitraria tangutorum Bobr of Qinghai-Tibetan Plateau. Sep. Sci. Technol. 2014, 49, 2897-2906. [CrossRef]

4. Liu, R.H. Health-Promoting Components of Fruits and Vegetables in the Diet. Adv. Nutr. 2013, 4, 384S-392S. [CrossRef] [PubMed]

5. Araki, R.; Yada, A.; Ueda, H.; Tominaga, K.; Isoda, H. Differences in the Effects of Anthocyanin Supplementation on Glucose and Lipid Metabolism According to the Structure of the Main Anthocyanin: A Meta-Analysis of Randomized Controlled Trials. Nutrients 2021, 13, 2003. [CrossRef]

6. Tian, Z.; Li, K.; Fan, D.; Zhao, Y.; Gao, X.; Ma, X.; Xu, L.; Shi, Y.; Ya, F.; Zou, J.; et al. Dose-dependent Effects of Anthocyanin Supplementation on Platelet Function in Subjects with Dyslipidemia: A Randomized Clinical Trial. eBioMedicine 2021, 70, 103533. [CrossRef]

7. Xu, Z.; Xie, J.; Zhang, H.; Pang, J.; Li, Q.; Wang, X.; Xu, H.; Sun, X.; Zhao, H.; Yang, Y.; et al. Anthocyanin Supplementation at Different Doses Improves Cholesterol Efflux Capacity in Subjects with Dyslipidemia-A Randomized Controlled Trial. Eur. J. Clin. Nutr. 2021, 75, 345-354. [CrossRef]

8. Zhao, Y.; Xu, H.; Tian, Z.; Wang, X.; Xu, L.; Li, K.; Gao, X.; Fan, D.; Ma, X.; Ling, W.; et al. Dose-dependent Reductions in Plasma Ceramides after Anthocyanin Supplementation are Associated with Improvements in Plasma Lipids and Cholesterol Efflux Capacity in Dyslipidemia: A Randomized Controlled Trial. Clin. Nutr. 2021, 40, 1871-1878. [CrossRef]

9. Park, S.; Choi, M.; Lee, M. Effects of Anthocyanin Supplementation on Reduction of Obesity Criteria: A Systematic Review and Meta-Analysis of Randomized Controlled Trials. Nutrients 2021, 13, 2121. [CrossRef]

10. Sandoval-Ramírez, B.A.; Catalán, Ú.; Fernández-Castillejo, S.; Rubió, L.; Macià, A.; Solà, R. Anthocyanin Tissue Bioavailability in Animals: Possible Implications for Human Health. A Systematic Review. J. Agric. Food Chem. 2018, 66, 11531-11543. [CrossRef]

11. Wang, D.D.; Li, Y.; Bhupathiraju, S.N.; Rosner, B.A.; Sun, Q.; Giovannucci, E.L.; Rimm, E.B.; Manson, J.E.; Willett, W.C.; Stampfer, M.J.; et al. Fruit and Vegetable Intake and Mortality. Circulation 2021, 143, 1642-1654. [CrossRef] [PubMed]

12. Kaushik, P.; Andújar, I.; Vilanova, S.; Plazas, M.; Gramazio, P.; Herraiz, F.J.; Brar, N.S.; Prohens, J. Breeding Vegetables with Increased Content in Bioactive Phenolic Acids. Molecules 2015, 20, 18464-18481. [CrossRef] [PubMed]

13. Lestario, L.N.; Muninggar, J.; Pudjihastuti, S. Anthocyanin and Recent Development as Functional Food. IOP Conf. Ser. Mater. Sci. Eng. 2019, 509, 012067. [CrossRef]

14. Petropoulos, S.A.; Sampaio, S.L.; Di Gioia, F.; Tzortzakis, N.; Rouphael, Y.; Kyriacou, M.C.; Ferreira, I. Grown to be BlueAntioxidant Properties and Health Effects of Colored Vegetables. Part I: Root Vegetables. Antioxidants 2019, 8, 617. [CrossRef]

15. Vanlalneihi, B.; Kumar, M.; Chhangte, L.; Gurung, A. Designing Nutraceutical Rich Vegetable Crops Through Conventional and Molecular Approaches. J. Pharmacogn. Phytochem. 2019, 8, 960-966.

16. Bendokas, V.; Stanys, V.; Mažeikienè, I.; Trumbeckaite, S.; Baniene, R.; Liobikas, J. Anthocyanins: From the Field to the Antioxidants in the Body. Antioxidants 2020, 9, 819. [CrossRef]

17. Speciale, A.; Saija, A.; Bashllari, R.; Molonia, M.S.; Muscara', C.; Occhiuto, C.; Cimino, F.; Cristani, M. Anthocyanins as Modulators of Cell Redox-Dependent Pathways in Non-Communicable Diseases. Curr. Med. Chem. 2020, 27, 1955-1996. [CrossRef] [PubMed]

18. Tena, N.; Martín, J.; Asuero, A.G. State of the Art of Anthocyanins: Antioxidant Activity, Sources, Bioavailability, and Therapeutic Effect in Human Health. Antioxidants 2020, 9, 451. [CrossRef]

19. Mannino, G.; Gentile, C.; Ertani, A.; Serio, G.; Bertea, C. Anthocyanins: Biosynthesis, Distribution, Ecological Role, and Use of Biostimulants to Increase Their Content in Plant Foods-A Review. Agriculture 2021, 11, 212. [CrossRef]

20. Sun, H.-L.; Wang, X.-Y.; Shang, Y.; Wang, X.-Q.; DU, G.-D.; Lü, D.-G. Preharvest Application of Melatonin Induces Anthocyanin Accumulation and Related Gene Upregulation in Red Pear (Pyrus ussuriensis). J. Integr. Agric. 2021, 20, 2126-2137. [CrossRef]

21. Wangiyana, W.; Aryana, I.G.P.M.; Dulur, N.W.D. Mycorrhiza Biofertilizer and Intercropping with Soybean Increase Anthocyanin Contents and Yield of Upland Red Rice under Aerobic Irrigation Systems. IOP Conf. Ser. Earth Environ. Sci. 2021, 637, 012087. [CrossRef]

22. Aliaño-González, M.J.; Jarillo, J.A.; Carrera, C.; Ferreiro-González, M.; Álvarez, J.; Palma, M.; Ayuso, J.; Barbero, G.F.; EspadaBellido, E. Optimization of a Novel Method Based on Ultrasound-Assisted Extraction for the Quantification of Anthocyanins and Total Phenolic Compounds in Blueberry Samples (Vaccinium corymbosum L.). Foods 2020, 9, 1763. [CrossRef] [PubMed] 
23. Carrera, C.; Aliaño-González, M.J.; Valaityte, M.; Ferreiro-González, M.; Barbero, G.F.; Palma, M. A Novel Ultrasound-Assisted Extraction Method for the Analysis of Anthocyanins in Potatoes (Solanum tuberosum L.). Antioxidants 2021, 10, 1375. [CrossRef]

24. Sancho-Galán, P.; Amores-Arrocha, A.; Jiménez-Cantizano, A.; Ferreiro-González, M.; Palacios, V.; Barbero, G.F. UltrasoundAssisted Extraction of Anthocyanins and Total Phenolic Compounds in Vitis vinifera L. 'Tempranillo' Winemaking Lees. Vitis 2019, 58, 39-47. [CrossRef]

25. Vázquez-Espinosa, M.; De Peredo, A.V.G.; González, M.F.; Carrera, C.; Palma, M.; Barbero, G.F.; Espada-Bellido, E. Assessment of Ultrasound Assisted Extraction as an Alternative Method for the Extraction of Anthocyanins and Total Phenolic Compounds from Maqui Berries (Aristotelia chilensis (Mol.) Stuntz). Agronomy 2019, 9, 148. [CrossRef]

26. Ginting, E.; Yulifianti, R.; Indriani, F.C. Selected Purple-fleshed Sweet Potato Genotypes with High Anthocyanin Contents. IOP Conf. Ser. Earth Environ. Sci. 2020, 456, 012023. [CrossRef]

27. Liu, Y.; Lin-Wang, K.; Espley, R.; Wang, L.; Li, Y.; Liu, Z.; Zhou, P.; Zeng, L.; Zhang, X.; Zhang, J.; et al. StMYB44 Negatively Regulates Anthocyanin Biosynthesis at High Temperatures in Tuber Flesh of Potato. J. Exp. Bot. 2019, 70, 3809-3824. [CrossRef]

28. Hamouz, K.; Lachman, J.; Bečka, D.; Pulkrábek, J. Effect of Growing Conditions and Storage on the Total Anthocyanin Content in Potatoes with Coloured Flesh. Plant Soil Environ. 2018, 64, 435-440. [CrossRef]

29. Reyes, L.F.; Miller, J.C.; Cisneros-Zevallos, L. Environmental Conditions Influence the Content and Yield of Anthocyanins and Total Phenolics in Purple- and Red-flesh Potatoes during Tuber Dvelopment. Am. J. Potato Res. 2004, 81, 187-193. [CrossRef]

30. Šulc, M.; Kotíková, Z.; Paznocht, L.; Pivec, V.; Hamouz, K.; Lachman, J. Changes in Anthocyanidin Levels during the Maturation of Color-fleshed Potato (Solanum tuberosum L.) tubers. Food Chem. 2017, 237, 981-988. [CrossRef]

31. Samaniego, I.; Espin, S.; Cuesta, X.; Arias, V.; Rubio, A.; Llerena, W.; Angós, I.; Carrillo, W. Analysis of Environmental Conditions Effect in the Phytochemical Composition of Potato (Solanum tuberosum) Cultivars. Plants 2020, 9, 815. [CrossRef] [PubMed]

32. Bellumori, M.; Silva, N.A.C.; Vilca, L.; Andrenelli, L.; Cecchi, L.; Innocenti, M.; Balli, D.; Mulinacci, N. A Study on the Biodiversity of Pigmented Andean Potatoes: Nutritional Profile and Phenolic Composition. Molecules 2020, 25, 3169. [CrossRef] [PubMed]

33. Giusti, M.M.; Polit, M.F.; Ayvaz, H.; Tay, D.; Manrique, I. Characterization and Quantification of Anthocyanins and Other Phenolics in Native Andean Potatoes. J. Agric. Food Chem. 2014, 62, 4408-4416. [CrossRef] [PubMed]

34. Hamouz, K.; Lachman, J.; Pazderů, K.; Tomasek, J.; Hejtmánková, K.; Pivec, V. Differences in anthocyanin content and antioxidant activity of potato tubers with different flesh colour. Plant Soil Environ. 2011, 57, 478-485. [CrossRef]

35. Kim, H.W.; Kim, S.R.; Lee, Y.M.; Jang, H.H.; Kim, J.B. Analysis of Variation in Anthocyanin Composition in Korean Coloured Potato Cultivars by LC-DAD-ESI-MS and PLS-DA. Potato Res. 2018, 61, 1-17. [CrossRef]

36. Lachman, J.; Hamouz, K.; Orsak, M.; Pivec, V.; Hejtmánková, K.; Pazderů, K.; Dvořák, P.; Čepl, J. Impact of Selected FactorsCultivar, Storage, Cooking and Baking on the Content of Anthocyanins in Coloured-flesh Potatoes. Food Chem. 2012, 133, 1107-1116. [CrossRef]

37. Parra-Galindo, M.-A.; Piñeros-Niño, C.; Soto-Sedano, J.C.; Mosquera-Vasquez, T. Chromosomes I and X Harbor Consistent Genetic Factors Associated with the Anthocyanin Variation in Potato. Agronomy 2019, 9, 366. [CrossRef]

38. Lachman, J.; Hamouz, K.; Šulc, M.; Orsák, M.; Pivec, V.; Hejtmánková, A.; Dvořák, P.; Čepl, J. Cultivar Differences of Total Anthocyanins and Anthocyanidins in Red and Purple-fleshed Potatoes and Their Relation to Antioxidant Activity. Food Chem. 2009, 114, 836-843. [CrossRef]

39. Lewis, C.E.; Walker, J.R.L.; Lancaster, J.E.; Sutton, K.H. Determination of Anthocyanins, Flavonoids and Phenolic Acids in Potatoes. I: Coloured Cultivars of Solanum tuberosum L. J. Sci. Food Agric. 1998, 77, 45-57. [CrossRef]

40. Ercoli, S.; Parada, J.; Bustamante, L.; Hermosín-Gutiérrez, I.; Contreras, B.; Cornejo, P.; Ruiz, A. Noticeable Quantities of Functional Compounds and Antioxidant Activities Remain after Cooking of Colored Fleshed Potatoes Native from Southern Chile. Molecules 2021, 26, 314. [CrossRef]

41. D'Amelia, V.; Sarais, G.; Fais, G.; Dessì, D.; Giannini, V.; Garramone, R.; Carputo, D.; Melito, S. Biochemical Characterization and Effects of Cooking Methods on Main Phytochemicals of Red and Purple Potato Tubers, a Natural Functional Food. Foods 2022, 11, 384. [CrossRef] [PubMed]

42. Ginting, E.; Utomo, J.S.; Restuono, J. Purple-fleshed Sweet Potato Genotypes as the Ingredients for Crisps and Noodle Making. E3S Web Conf. 2021, 306, 01048. [CrossRef]

43. Stommel, J. Genetic Enhancement of Tomato Fruit Nutritive Value. In Genetic Improvement of Solanaceous Crops, Tomato; Razdan, M.K., Mattoo, A.K., Eds.; Science Publishers: Enfield, NH, USA, 2007; Volume 2, pp. 193-238. ISBN 978-1-57808-179-0. [CrossRef]

44. Mehta, R.A.; Cassol, T.; Li, N.; Ali, N.; Handa, A.K.; Mattoo, A.K. Engineered Polyamine Accumulation in Tomato Enhances Phytonutrient Content, Juice Quality, and Vine Life. Nat. Biotechnol. 2002, 20, 613-618. [CrossRef] [PubMed]

45. Butelli, E.; Titta, L.; Giorgio, M.; Mock, H.-P.; Matros, A.; Peterek, S.; Schijlen, E.G.W.M.; Hall, R.D.; Bovy, A.G.; Luo, J.; et al. Enrichment of Tomato Fruit with Health-promoting Anthocyanins by Expression of Select Transcription Factors. Nat. Biotechnol. 2008, 26, 1301-1308. [CrossRef]

46. Gonzali, S.; Mazzucato, A.; Perata, P. Purple as a Tomato: Towards High Anthocyanin Tomatoes. Trends Plant Sci. 2009, 14, $237-241$. [CrossRef] [PubMed]

47. Maligeppagol, M.; Chandra, G.S.; Navale, P.M.; Deepa, H.; Rajeev, P.R.; Ashokan, R.; Prasad Babu, K.; Bujji Babu, C.S.; Rao, V.K.; Krishna Kumar, N.K. Anthocyanin Enrichment of Tomato (Solanum lycopersicum L.) Fruit by Metabolic Engineering. Curr. Sci. 2013, 105, 72-80. 
48. Blando, F.; Berland, H.; Maiorano, G.; Durante, M.; Mazzucato, A.; Picarella, M.E.; Nicoletti, I.; Gerardi, C.; Mita, G.; Andersen, Ø.M. Nutraceutical Characterization of Anthocyanin-Rich Fruits Produced by "Sun Black" Tomato Line. Front. Nutr. 2019, 6, 133. [CrossRef] [PubMed]

49. Jones, C.M.; Mes, P.; Myers, J.R. Characterization and Inheritance of the Anthocyanin fruit (Aft) Tomato. J. Hered. 2003, 94, 449-456. [CrossRef]

50. Mes, P.J.; Boches, P.; Myers, J.R.; Durst, R. Characterization of Tomatoes Expressing Anthocyanin in the Fruit. J. Am. Soc. Hortic. Sci. 2008, 133, 262-269. [CrossRef]

51. Rick, C.M. Tomato. Genet. Coop. Rept. 1959, 9, 41-42.

52. Kurina, A.B.; Solovieva, A.E.; Khrapalova, I.A.; Artemyeva, A.M. Biochemical Composition of Tomato Fruits of Various Colors. Vavilov J. Genet. Breed. 2021, 25, 514-527. [CrossRef] [PubMed]

53. Kubow, S.; Iskandar, M.M.; Sabally, K.; Azadi, B.; Ekbatan, S.S.; Kumarathasan, P.; Das, D.D.; Prakash, S.; Burgos, G.; Felde, T.Z Biotransformation of Anthocyanins from two Purple-fleshed Sweetpotato Accessions in a Dynamic Gastrointestinal System. Food Chem. 2016, 192, 171-177. [CrossRef] [PubMed]

54. Salehi, B.; Sharifi-Rad, J.; Cappellini, F.; Reiner, Ž.; Zorzan, D.; Imran, M.; Sener, B.; Kilic, M.; El-Shazly, M.; Fahmy, N.M.; et al. The Therapeutic Potential of Anthocyanins: Current Approaches Based on Their Molecular Mechanism of Action. Front. Pharmacol. 2020, 11, 1300. [CrossRef] [PubMed]

55. Isah, T. Stress and Defense Responses in Plant Secondary Metabolites Production. Biol. Res. 2019, 52, 39. [CrossRef] [PubMed]

56. Seca, A.M.L.; Pinto, D.C.G.A. Plant Secondary Metabolites as Anticancer Agents: Successes in Clinical Trials and Therapeutic Application. Int. J. Mol. Sci. 2018, 19, 263. [CrossRef] [PubMed]

57. Wang, S.; Alseekh, S.; Fernie, A.R.; Luo, J. The Structure and Function of Major Plant Metabolite Modifications. Mol. Plant 2019, 12, 899-919. [CrossRef]

58. Oertel, A.; Matros, A.; Hartmann, A.; Arapitsas, P.; Dehmer, K.J.; Martens, S.; Mock, H.-P. Metabolite Profiling of Red and Blue Potatoes Revealed Cultivar and Tissue Specific Patterns for Anthocyanins and other Polyphenols. Planta 2017, 246, $281-297$. [CrossRef]

59. Drapal, M.; Rossel, G.; Heider, B.; Fraser, P.D. Metabolic Diversity in Sweet Potato (Ipomoea batatas, Lam.) Leaves and Storage Roots. Hortic. Res. 2019, 6, 2. [CrossRef]

60. Bennett, A.A.; Mahood, E.H.; Fan, K.; Moghe, G.D. Untargeted Metabolomics of Purple and Orange-fleshed Sweet Potatoes Reveals a Large Structural Diversity of Anthocyanins and Flavonoids. Sci. Rep. 2021, 11, 16408. [CrossRef]

61. Tohge, T.; Scossa, F.; Wendenburg, R.; Frasse, P.; Balbo, I.; Watanab, M.; Alseekh, S.; Jadhav, S.S.; Delfin, J.C.; Lohse, M.; et al. Exploiting Natural Variation in Tomato to Define Pathway Structure and Metabolic Regulation of Fruit Polyphenolics in the Lycopersicum Complex. Mol. Plant 2020, 13, 1027-1046. [CrossRef]

62. Smeriglio, A.; Barreca, D.; Bellocco, E.; Trombetta, D. Chemistry, Pharmacology and Health Benefits of Anthocyanins. Phytother. Res. 2016, 30, 1265-1286. [CrossRef]

63. Booij-James, I.S.; Dube, S.K.; Jansen, M.; Edelman, M.; Mattoo, A.K. Ultraviolet-B Radiation Impacts Light-Mediated Turnover of the Photosystem II Reaction Center Heterodimer in Arabidopsis Mutants Altered in Phenolic Metabolism. Plant Physiol. 2000, 124, 1275-1284. [CrossRef]

64. Emiliani, J.; Grotewold, E.; Ferreyra, M.L.F.; Casati, P. Flavonols Protect Arabidopsis Plants against UV-B Deleterious Effects. Mol. Plant 2013, 6, 1376-1379. [CrossRef] [PubMed]

65. Kong, J.-M.; Chia, L.-S.; Goh, N.-K.; Chia, T.-F.; Brouillard, R. Analysis and Biological Activities of Anthocyanins. Phytochemistry 2003, 64, 923-933. [CrossRef]

66. Liu, Y.; Tikunov, Y.; Schouten, R.E.; Marcelis, L.F.M.; Visser, R.G.F.; Bovy, A. Anthocyanin Biosynthesis and Degradation Mechanisms in Solanaceous Vegetables: A Review. Front. Chem. 2018, 6, 52. [CrossRef] [PubMed]

67. Pojer, E.; Mattivi, F.; Johnson, D.; Stockley, C.S. The Case for Anthocyanin Consumption to Promote Human Health: A Review. Comp. Rev. Food Sci. Food Saf. 2013, 12, 483-508. [CrossRef]

68. Sarni, P.; Fulcrand, H.; Souillol, V.; Souquet, J.-M.; Cheynier, V. Mechanisms of Anthocyanin Degradation in Grape must-like Model Solutions. J. Sci. Food Agric. 1995, 69, 385-391. [CrossRef]

69. Pascual-Teresa, S.; Sanchez-Ballesta, M.Y. Anthocyanins: From Plant to Health. Phytochem. Rev. 2008, 6, 281-299. [CrossRef]

70. Boss, P.; Davies, C.; Robinson, S. Expression of Anthocyanin Biosynthesis Pathway Genes in Red and White Grapes. Plant Mol. Biol. 1996, 32, 565-569. [CrossRef]

71. Tohge, T.; Nishiyama, Y.; Hirai, M.Y.; Yano, M.; Nakajima, J.-I.; Awazuhara, M.; Inoue, E.; Takahashi, H.; Goodenowe, D.B.; Kitayama, M.; et al. Functional Genomics by Integrated Analysis of Metabolome and Transcriptome of Arabidopsis Plants Over-expressing an MYB Transcription Factor. Plant J. 2005, 42, 218-235. [CrossRef]

72. Nakajima, J.; Tanaka, Y.; Yamazaki, M.; Saito, K. Reaction Mechanism from Leu-coanthocyanidin to Anthocyanidin 3-glucoside, a Key Reaction for Coloring in Anthocyanin Biosynthesis. J. Biol. Chem. 2001, 276, 25797-25803. [CrossRef] [PubMed]

73. Davies, K.M.; Schwinn, K.E. Molecular Biology and Biotechnology of Flavonoid Biosynthesis. In Flavonoids: Chemistry, Biochemistry and Applications; Anderson, Ø.M., Markham, K.R., Eds.; CRC; Taylor \& Francis: Boca Raton, FL, USA, 2006 ; pp. 143-218.

74. Tanaka, Y.; Katsumoto, Y.; Brugliera, F.; Mason, J. Genetic Engineering in Floriculture. Plant Cell Tissue Org. Cult. 2005, 80, 1-24. [CrossRef] 
75. Chen, K.; Wei, X.; Zhang, J.; Pariyani, R.; Jokioja, J.; Kortesniemi, M.; Linderborg, K.M.; Heinonen, J.; Sainio, T.; Zhang, Y.; et al. Effects of Anthocyanin Extracts from Bilberry (Vaccinium myrtillus L.) and Purple Potato (Solanum tuberosum L. var. 'Synkeä Sakari') on the Plasma Metabolomic Profile of Zucker Diabetic Fatty Rats. J. Agric. Food Chem. 2020, 68, 9436-9450. [CrossRef] [PubMed]

76. Yang, X.; Wang, J.; Xia, X.; Zhang, Z.; He, J.; Nong, B.; Luo, T.; Feng, R.; Wu, Y.; Pan, Y.; et al. OsTTG1, a WD40 Repeat Gene, Regulates Anthocyanin Biosynthesis in Rice. Plant J. 2021, 107, 198-214. [CrossRef] [PubMed]

77. Feller, A.; Machemer, K.; Braun, E.L.; Grotewold, E. Evolutionary and Comparative Analysis of MYB and bHLH Plant Transcription Factors. Plant J. 2011, 66, 94-116. [CrossRef]

78. LaFountain, A.M.; Yuan, Y. Repressors of Anthocyanin Biosynthesis. New Phytol. 2021, 231, 933-949. [CrossRef]

79. Dhar, M.K.; Sharma, R.; Koul, A.; Kaul, S. Development of Fruit Color in Solanaceae: A story of two biosynthetic pathways. Brief. Funct. Genom. 2015, 14, 199-212. [CrossRef]

80. Holton, T.A.; Cornish, E.C. Genetics and Biochemistry of Anthocyanin Biosynthesis. Plant Cell 1995, 7, 1071-1083. [CrossRef]

81. Tanaka, Y.; Sasaki, N.; Ohmiya, A. Biosynthesis of Plant Pigments: Anthocyanins, Betalains and Carotenoids. Plant J. 2008, 54, 733-749. [CrossRef]

82. Parra-Galindo, M.A.; Soto-Sedano, J.C.; Mosquera-Vásquez, T.; Roda, F. Pathway-based Analysis of Anthocyanin Diversity in Diploid Potato. PLoS ONE 2021, 16, e0250861. [CrossRef]

83. Strygina, K.V.; Kochetov, A.V.; Khlestkina, E.K. Genetic Control of Anthocyanin Pigmentation of Potato Tissues. BMC Genet. 2019, 20, 27. [CrossRef] [PubMed]

84. Strygina, K.V.; Khlestkina, E.K. Anthocyanins Synthesis in Potato (Solanum tuberosum L.): Genetic Markers for Smart Breeding. Agric. Biol. 2017, 52, 37-49. [CrossRef]

85. Zhang, D.; Tan, Y.; Dong, F.; Zhang, Y.; Huang, Y.; Zhou, Y.; Zhao, Z.; Yin, Q.; Xie, X.; Gao, X.; et al. The Expression of IbMYB1 Is Essential to Maintain the Purple Color of Leaf and Storage Root in Sweet Potato [Ipomoea batatas (L.) Lam]. Front. Plant Sci. 2021, 12, 688707. [CrossRef]

86. Zhang, L.; Yu, Y.; Shi, T.; Kou, M.; Sun, J.; Xu, T.; Li, Q.; Wu, S.; Cao, Q.; Hou, W.; et al. Genome-wide Analysis of Expression Quantitative Trait Loci (eQTLs) Reveals the Regulatory Architecture of Gene Expression Variation in the Storage Roots of Sweet Potato. Hortic. Res. 2020, 7, 90. [CrossRef] [PubMed]

87. Ning, Z.; Hu, K.; Zhou, Z.; Zhao, D.; Tang, J.; Wang, H.; Li, L.; Ding, C.; Chen, X.; Yao, G. IbERF71, with IbMYB340 and IbbHLH2, Coregulates Anthocyanin Accumulation by Binding to the IbANS1 Promoter in Purple-fleshed Sweetpotato (Ipomoea batatas L.). Plant Cell Rep. 2021, 40, 157-169. [CrossRef] [PubMed]

88. Dong, W.; Niu, L.; Gu, J.; Gao, F. Isolation of a WD40-repeat Gene Regulating Anthocyanin Biosynthesis in Storage Roots of Purple-fleshed Sweet Potato. Acta Physiol. Plant. 2014, 36, 1123-1132. [CrossRef]

89. Qin, Z.; Hou, F.; Li, A.; Dong, S.; Huang, C.; Wang, Q.; Zhang, L. Comparative Analysis of Full-length Transcriptomes Based on Hybrid Population Reveals Regulatory Mechanisms of Anthocyanin Biosynthesis in Sweet Potato (Ipomoea batatas (L.) Lam). BMC Plant Biol. 2020, 20, 299. [CrossRef]

90. Cao, X.; Qiu, Z.; Wang, X.; Van Giang, T.; Liu, X.; Wang, J.; Wang, X.; Gao, J.; Guo, Y.; Du, Y.; et al. A Putative R3 MYB Repressor is the Candidate Gene Underlying Atroviolacium, a Locus for Anthocyanin Pigmentation in Tomato Fruit. J. Exp. Bot. 2017, 68, 5745-5758. [CrossRef]

91. Kiferle, C.; Fantini, E.; Bassolino, L.; Povero, G.; Spelt, C.; Buti, S.; Giuliano, G.; Quattrocchio, F.M.; Koes, R.; Perata, P.; et al. Tomato R2R3-MYB Proteins SIANT1 and SIAN2: Same Protein Activity, Different Roles. PLoS ONE 2015, 10, e0136365. [CrossRef]

92. Li, Z.; Peng, R.; Tian, Y.; Han, H.; Xu, J.; Yao, Q. Genome-Wide Identification and Analysis of the MYB Transcription Factor Superfamily in Solanum lycopersicum. Plant Cell Physiol. 2016, 57, 1657-1677. [CrossRef]

93. Zhi, J.; Liu, X.; Li, D.; Huang, Y.; Yan, S.; Cao, B.; Qiu, Z. CRISPR/Cas9-mediated SlAN2 Mutants Reveal Various Regulatory Models of Anthocyanin Biosynthesis in Tomato Plant. Plant Cell Rep. 2020, 39, 799-809. [CrossRef] [PubMed]

94. Yan, S.; Chen, N.; Huang, Z.; Li, D.; Zhi, J.; Yu, B.; Liu, X.; Cao, B.; Qiu, Z. Anthocyanin Fruit Encodes an R2R3-MYB Transcription Factor, SlAN2-like, Activating the Transcription of SIMYBATV to Fine-tune Anthocyanin Content in Tomato Fruit. New Phytol. 2020, 225, 2048-2060. [CrossRef]

95. Ezkurdia, I.; Tress, M.L.; Valencia, A. Alternative Splicing. In Encyclopedia of Biophysics; Roberts, G.C.K., Ed.; Springer: Berlin/Heidelberg, Germany, 2013; pp. 48-53. [CrossRef]

96. Colanero, S.; Perata, P.; Gonzali, S. What's behind Purple Tomatoes? Insight into the Mechanisms of Anthocyanin Synthesis in Tomato Fruits. Plant Physiol. 2020, 182, 1841-1853. [CrossRef] [PubMed]

97. Xiong, C.; Luo, D.; Lin, A.; Zhang, C.; Shan, L.; He, P.; Li, B.; Zhang, Q.; Hua, B.; Yuan, Z.; et al. A Tomato B-box Protein SlBBX20 Modulates Carotenoid Biosynthesis by Directly Activating PHYTOENE SYNTHASE 1 and is Targeted for 26S Proteasomemediated Degradation. New Phytol. 2019, 221, 279-294. [CrossRef] [PubMed]

98. Luo, D.; Xiong, C.; Lin, A.; Zhang, C.; Sun, W.; Zhang, J.; Yang, C.; Lu, Y.; Li, H.; Ye, Z.; et al. SlBBX20 Interacts with the COP9 Signalosome Subunit SICSN5-2 to Regulate Anthocyanin Biosynthesis by Activating SIDFR Expression in Tomato. Hortic. Res. 2021, 8, 163. [CrossRef]

99. Garg, M.; Sharma, N.; Sharma, S.; Kapoor, P.; Kumar, A.; Chunduri, V.; Arora, P. Biofortified Crops Generated by Breeding, Agronomy, and Transgenic Approaches Are Improving Lives of Millions of People around the World. Front. Nutr. $2018,5,12$. [CrossRef] 
100. Mwanga, R.O.M.; Swanckaert, J.; de Silva Pereira, G.; Andrade, M.I.; Makunde, G.; Grüneberg, W.J.; Kreuze, J.; David, M.; De Boeck, B.; Carey, E.; et al. Breeding Progress for Vitamin A, Iron and Zinc Biofortification, Drought Tolerance, and Sweetpotato Virus Disease Resistance in Sweetpotato. Front. Sustain. Food Syst. 2021, 5, 616674. [CrossRef]

101. Lockyer, S.; White, A.; Buttriss, J.L. Biofortified Crops for Tackling Micronutrient Deficiencies—What Impact are These Having in Developing Countries and Could They be of Relevance within Europe? Nutr. Bull. 2018, 43, 319-357. [CrossRef]

102. Parulekar, Y.R.; Haldankar, P.M.; Dalvi, N.V.; Salvi, B.R.; Bhattacharyya, T. Nutraceuticals and Their Biofortification in Vegetable Crops: A review. Adv. Agric. Res. Technol. J. 2019, 3, 219-229.

103. Xu, J.; Su, X.; Lim, S.; Griffin, J.; Carey, E.; Katz, B.; Tomich, J.; Smith, J.C.; Wang, W. Characterization and Stability of Anthocyanins in Purple-fleshed Sweetpotato P40. Food Chem. 2015, 186, 90-96. [CrossRef]

104. Brown, C.R.; Vales, I.; Yilma, S.; James, S.; Charlton, B.; Culp, D.; Dan, H.; Clinton, S.; Eric, F.; Mark, P.; et al. "AmaRosa," a Red Skinned, Red Fleshed Fingerling with High Phytonutrient Value. Am. J. Pot. Res. 2012, 89, 249-254. [CrossRef]

105. Shock, C.C.; Brown, C.R.; Sathuvalli, V.; Charlton, B.A.; Yilma, S.; Hane, D.C.; Quick, R.; Rykbost, K.A.; James, S.R.; Mosley, A.R.; et al. TerraRossa: A Mid-Season Specialty Potato with Red Flesh and Skin and Resistance to Common Scab and Golden Cyst Nematode. Am. J. Potato Res. 2018, 95, 597-605. [CrossRef]

106. Vales, M.I.; Brown, C.R.; Yilma, S.; Hane, D.C.; James, S.R.; Shock, C.C.; Charlton, B.A.; Karaagac, E.; Mosley, A.R.; Culp, D.; et al. Purple Pelisse: A Specialty 'Fingerling' Potato with Purple Skin and Flesh and Medium Specific Gravity. Am. J. Potato Res. 2012, 89, 306-314. [CrossRef]

107. Mazzucato, A.; Willems, D.; Bernini, R.; Picarella, M.E.; Santangelo, E.; Ruiu, F.; Tilesi, F.; Soressi, G.P. Novel Phenotypes Related to the Breeding of Purple-fruited Tomatoes and Effect of Peel Extracts on Human Cancer Cell Proliferation. Plant Physiol. Biochem. 2013, 72, 125-133. [CrossRef] [PubMed]

108. Myers, J. Breeding Tomatoes for Increased Flavonoids. In: Strengthening Community Seed Systems. In Proceedings of the 6th Organic Seed Growers Conference, Port Townsend, WA, USA, 19-21 January 2012; pp. 50-51.

109. Kang, S.-I.; Rahim, A.; Afrin, K.S.; Jung, H.-J.; Kim, H.-T.; Park, J.-I.; Nou, I.-S. Expression of Anthocyanin Biosynthesis-related Genes Reflects the Peel Color in Purple Tomato. Hortic. Environ. Biotechnol. 2018, 59, 435-445. [CrossRef]

110. da Silva Souza, M.A.; Peres, L.; Freschi, J.R.; Purgatto, E.; Lajolo, F.M.; Hassimotto, N.M.A. Changes in Flavonoid and Carotenoid Profiles Alter Volatile Organic Compounds in Purple and Orange Cherry Tomatoes Obtained by Allele Introgression. J. Sci. Food Agric. 2020, 100, 1662-1670. [CrossRef]

111. Hazra, P.; Longjam, M.; Chattopadhyay, A. Stacking of Mutant Genes in the Development of "Purple Tomato" Rich in both Lycopene and Anthocyanin Contents. Sci. Hortic. 2018, 239, 253-258. [CrossRef]

112. Sestari, I.; Zsögön, A.; Rehder, G.G.; Teixeira, L.D.L.; Hassimotto, N.M.A.; Purgatto, E.; Benedito, V.A.; Peres, L. Near-isogenic Lines Enhancing Ascorbic Acid, Anthocyanin and Carotenoid Content in Tomato (Solanum lycopersicum L. cv Micro-Tom) as a Tool to Produce Nutrient-rich Fruits. Sci. Hortic. 2014, 175, 111-120. [CrossRef]

113. Garg, M.; Chawla, M.; Chunduri, V.; Kumar, R.; Sharma, S.; Sharma, N.K.; Kaur, N.; Kumar, A.; Mundey, J.K.; Saini, M.K. Transfer of Grain Colors to Elite Wheat 532 Cultivars and Their Characterization. J. Cereal Sci. 2016, 71, 138-144. [CrossRef]

114. Jongstra, R.; Mwangi, M.N.; Burgos, G.; Zeder, C.; Low, J.W.; Mzembe, G.; Liria, R.; Penny, M.; Andrade, M.I.; Fairweather-Tait, S.; et al. Iron Absorption from Iron-Biofortified Sweetpotato Is Higher Than Regular Sweetpotato in Malawian Women while Iron Absorption from Regular and Iron-Biofortified Potatoes Is High in Peruvian Women. J. Nutr. 2020, 150, 3094-3102. [CrossRef]

115. Luthra, S.K.; Gupta, V.K.; Kumar, R.; Rawal, S.; Lal, M.; Kumar, S.; Dalamu; Tiwari, J.K.; Raigond, P.; Bandana; et al. Kufri Neelkanth: Purple Skin Coloured Specialty Potato Variety of India. Potato J. 2020, 47, 1-8.

116. Park, Y.; Cho, J.; Cho, H.; Yi, J.; Seo, H.; Choung, M. A New Potato Cultivar "Hongyoung", with Red Skin and Flesh Color, and High Concentrations of Anthocyanins. Korean J. Breed. Sci. 2009, 41, 502-506.

117. Park, Y.; Cho, J.; Cho, H.; Yi, J.; Seo, H.; Chung, M. A New Potato Cultivar "Jayoung", with High Concentration of Anthocyanin. Korean J. Breed. Sci. 2009, 41, 51-55. [CrossRef]

118. Hillebrand, S.; Naumann, H.; Kitzinski, N.; Kohler, N.; Winterhalter, P. Isolation and Characterization of Anthocyanins from Blue-fleshed Potatoes (Solanum tuberosum L.). Food Red. Global Sci. 2009, 3, 96-101.

119. Lee, M.J.; Park, J.S.; Choi, D.S.; Jung, M.Y. Characterization and Quantitation of Anthocyanins in Purple-Fleshed Sweet Potatoes Cultivated in Korea by HPLC-DAD and HPLC-ESI-QTOF-MS/MS. J. Agric. Food Chem. 2013, 61, 3148-3158. [CrossRef] [PubMed]

120. Montilla, C.E.; Hillebrand, S.; Winterhalter, P. Anthocyanins in Purple Sweetpotato (Ipomoea batatas L.) Varieties. Fruit Veg. Cereal Sci. Biotechnol. 2011, 5, 19-24.

121. Lim, S.-H.; Kim, D.-H.; Kim, J.K.; Lee, J.-Y.; Ha, S.-H. A Radish Basic Helix-Loop-Helix Transcription Factor, RsTT8 Acts a Positive Regulator for Anthocyanin Biosynthesis. Front. Plant Sci. 2017, 8, 1917. [CrossRef]

122. Sharma, S.; Holme, I.B.; Dionisio, G.; Kodama, M.; Dzhanfezova, T.; Joernsgaard, B.; Brinch-Pedersen, H. Cyanidin Based Anthocyanin Biosynthesis in Orange Carrot is Restored by Expression of AmRosea1 and AmDelila, MYB and bHLH Transcription Factors. Plant Mol. Biol. 2020, 103, 443-456. [CrossRef]

123. Xu, Z.-S.; Yang, Q.-Q.; Feng, K.; Xiong, A.-S. Changing Carrot Color: Insertions in DcMYB7 Alter the Regulation of Anthocyanin Biosynthesis and Modification. Plant Physiol. 2019, 181, 195-207. [CrossRef]

124. Ge, J.; Hu, Y.; Wang, H.; Huang, Y.; Zhang, P.; Liao, Z.; Chen, M. Profiling of Anthocyanins in Transgenic Purple Fleshed Sweetpotatoes by HPLC-MS/MS. J. Sci. Food Agric. 2017, 97, 4995-5003. [CrossRef] 
125. Hassanin, A.A.; Saad, A.M.; Bardisi, E.A.; Salama, A.; Sitohy, M.Z. Transfer of Anthocyanin Accumulating Delila and Rosea1 Genes from the Transgenic Tomato Micro-Tom Cultivar to Moneymaker Cultivar by Conventional Breeding. J. Agric. Food Chem. 2020, 68, 10741-10749. [CrossRef] [PubMed]

126. Jian, W.; Cao, H.; Yuan, S.; Liu, Y.; Lu, J.; Lu, W.; Li, N.; Wang, J.; Zou, J.; Tang, N.; et al. SlMYB75, an MYB-type Transcription Factor, Promotes Anthocyanin Accumulation and Enhances Volatile Aroma Production in Tomato Fruits. Hortic. Res. $2019,6,22$. [CrossRef] [PubMed]

127. Schifferstein, H.N.J.; Wehrle, T.; Carbon, C.-C. Consumer Expectations for Vegetables with Typical and Atypical Colors: The Case of Carrots. Food Qual. Prefer. 2019, 72, 98-108. [CrossRef]

128. Colanero, S.; Tagliani, A.; Perata, P.; Gonzali, S. Alternative Splicing in the Anthocyanin Fruit Gene Encoding an R2R3 MYB Transcription Factor Affects Anthocyanin Biosynthesis in Tomato Fruits. Plant Commun. 2020, 1, 100006. [CrossRef]

129. Van Der Straeten, D.; Bhullar, N.K.; De Steur, H.; Gruissem, W.; MacKenzie, D.; Pfeiffer, W.; Qaim, M.; Slamet-Loedin, I.; Strobbe, S.; Tohme, J.; et al. Multiplying the Efficiency and Impact of Biofortification through Metabolic Engineering. Nat. Commun. 2020, 11, 5203. [CrossRef]

130. KC, K.B.; Dias, G.M.; Veeramani, A.; Swanton, C.J.; Fraser, D.; Steinke, D.; Lee, E.; Wittman, H.; Farber, J.M.; Dunfield, K.; et al. When too much isn't enough: Does Current Food Production Meet Global Nutritional needs? PLoS ONE 2018, 13, e0205683. [CrossRef]

131. Mason-D'Croz, D.; Bogard, J.R.; Sulser, T.B.; Cennachi, N.; Dunston, S.; Herrero, M.; Wiebe, K. Gaps between Fruit and Vegetable Production, Demand, and Recommended Consumption at Global and National Levels: An Integrated Modelling Study. Lancet Public Health 2019, 3, e319-e329. [CrossRef] 